\title{
Comparative Localization of Two Forms of Glutamic Acid Decarboxylase and Their mRNAs in Rat Brain Supports the Concept of Functional Differences between the Forms
}

\author{
Monique Esclapez, ${ }^{1,3}$ Niranjala J. K. Tillakaratne, ${ }^{4}$ Daniel L. Kaufman, ${ }^{5}$ Allan J. Tobin, ${ }^{1,2,4}$ \\ and Carolyn R. Houser ${ }^{1,3,6}$ \\ ${ }^{1}$ Brain Research and ${ }^{2}$ Molecular Biology Institutes, and Departments of ${ }^{3}$ Anatomy and Cell Biology, ${ }^{4}$ Biology, and \\ ${ }^{5}$ Psychiatry and Biobehavioral Sciences, University of California, Los Angeles, and ${ }^{6}$ Neurology and Research Services, VA \\ Medical Center, West Los Angeles, Wadsworth Division, Los Angeles, California 90024
}

Two isoforms of glutamic acid decarboxylase (GAD67 and GAD65) and their mRNAs were localized in the rat brain by immunohistochemistry and nonradioactive in situ hybridization methods with digoxigenin-labeled cRNA probes. In most brain regions, both GAD isoforms were present in neuronal cell bodies as well as axon terminals. A few populations of neurons, such as those in the reticular nucleus of the thalamus, exhibited similar cell body labeling for both GADs. However, in many brain regions, the cell bodies that were immunoreactive for GAD67 were often more numerous than those that were immunoreactive for GAD65. In contrast, the density (quantity) of GAD65-immunoreactive axon terminals was higher than that of GAD67-immunoreactive terminals.

Strong parallels were observed between the intensity of immunohistochemical labeling of cell bodies and the levels of mRNA labeling for both GAD isoforms. Many groups of GAD-containing cell bodies were distinctly labeled for GAD67, and these same groups of neurons were heavily labeled for GAD67 mRNA. Such neurons included Purkinje cells of the cerebellar cortex, nonpyramidal cells in the cerebral cortex, and neurons of the reticular nucleus of the thalamus. Similar parallels in labeling were observed for GAD65 and its mRNA. Distinct cell body labeling for the protein and associated high levels of GAD65 mRNA were found in neurons of the reticular nucleus of the thalamus and periglomerular cells in the olfactory bulb. However, many cell bodies were not readily labeled for GAD65 with immunohistochemical methods. Such absence or weakness of cell body labeling for the protein was associated with low or moderate levels of GAD65 mRNA. Even though light cell body staining was frequently observed for GAD65 and its mRNA, strong axon terminal labeling for GAD65 was present. Thus, in the deep cerebellar nuclei to which the Purkinje cells of the cerebellar cortex

\footnotetext{
Reccived July 26, 1993; revised Aug. 30, 1993; accepted Sept. 9, 1993.

We thank Dr. David Gottlieb for generously providing the GAD-6 antibody; Dr. Mark Erlander for helpful discussions; Siroun Tahtakran for superb assistance work on the in situ hybridization experiments; Donald Chang and Bruce I Iavens for excellent immunohistochemical and photographic work; and Bob Weatherwax for providing GAD protein extracts. This research was supported by VA Medical Research Funds (C.R.H.); NIH Grants NS29231 (C.R.H.); NS21908 (A. V. Delgado-Escueta and C.R.H.); NS20356 and NS22256 (A.J.T.); and the Del Duca and Philippe Foundations (M.E.).

Correspondence should be addressed to Dr. M. Fsclapez, BRI 73-364 C.HS, Brain Research Institute, UCLA, Los Angeles, CA 90024-1761.

Copyright (C) 1994 Society for Neuroscience $0270-6474 / 94 / 141834-22 \$ 05.00 / 0$
}

project, strong terminal labeling was observed for both GAD isoforms even though only light cell body labeling of the Purkinje cells was obtained for GAD65 and its mRNA.

The findings suggest that the two isoforms of GAD are present in most classes of GABA neurons but that they are not similarly distributed within the neurons. GAD67 is present in readily detectable amounts in many GAD-containing cell bodies whereas GAD65 is particularly prominent in many axon terminals. In addition, neurons that express either form of GAD mRNA also express the corresponding protein. Levels of labeling for the GAD mRNAs suggest that, under normal conditions, the synthesis of GAD65 is frequently lower than that of GAD67. However, strong terminal labeling for GAD65 suggests that this protein accumulates in the axon terminals. Different levels of GAD67 and GAD65 as well as differential intraneuronal localizations may be related to different functions and associated rates of synthesis of the two proteins.

IKey words: glutamate decarboxylase, glutamic acid decarboxylase (GAD), GABA, immunohistochemistry, nonradioactive in situ hybridization, digoxigenin, cRNA probe]

As the enzyme responsible for the synthesis of GABA, glutamic acid decarboxylase (GAD) plays a critically important role in nervous system function. Recently, two forms of GAD, each encoded by a different gene, have been identified (for reviews, see Erlander and Tobin, 1991; Erlander et al., 1991; Martin and Rimvall, 1993). Both GAD forms are present in the CNS, and each is capable of actively synthesizing GABA. Each of these two forms is highly conserved among vertebrates and shares more than $95 \%$ identity among the amino acid sequences of the cat, rat, mouse, and human proteins (Kaufman et al., 1986; Kobayashi et al., 1987; Julien et al., 1990; Katarova et al., 1990; Wyborski et al., 1990; Erlander et al., 1991; Bu et al., 1992). However, in the same species these two GAD proteins differ substantially in their amino acid sequence (with only $65 \%$ identity in the rat), their molecular sizes $(65,000$ and 67,000$)$, their interaction with the cofactor pyridoxal 5'-phosphate, and their regulatory control (Erlander et al., 1991; Kaufman et al., 1991; Martin et al., 1991a,b; Rimvall and Martin, 1992; Soghomonian et al., 1992; Martin and Rimvall, 1993; Rimvall et al., 1993).

These differences between the two isoforms suggest that they could play different functional roles in the CNS, and therefore 
it is important to understand how the two proteins are expressed by the different populations of GABAergic neurons and how they are localized in the functionally different compartments of these neurons. Such information can now be obtained by the use of antibodies that primarily recognize each of the GAD proteins (Chang and Gottlieb, 1988; Kaufman et al., 1991). Furthermore, knowledge of the sequences of the cDNAs for both GAD forms has allowed synthesis of cRNA probes that are selective for the two GAD mRNAs (Erlander et al., 1991). With these multiple reagents, it is possible to determine and compare the neuronal distributions of the two GAD proteins and their respective mRNAs with immunohistochemical and in situ hybridization methods.

Previous studies have demonstrated that the $\mathrm{mRNAs}$ for the two forms of GAD referred to as GAD65 and GAD67 are present in many of the same groups of GABA neurons but often in varying amounts (Erlander et al., 1991; Mercugliano et al., 1992b; Esclapez et al., 1993; Feldblum et al., 1993). Furthermore, double-labeling studies have confirmed the presence of the two GAD mRNAs in the same neurons in several brain regions (Mercugliano et al., 1992b; M. Esclapez and C. R. Houser, unpublished observations). These findings suggest that many GABA neurons contain both GAD isoforms for the synthesis of GABA. Iowever, if the two isoforms subserve different functions, some differences in their neuronal localization and relative abundance might be expected.

The first goal of this study was to determine if the two proteins have different intraneuronal localizations. Initial studies of the cerebellar cortex have suggested that the localization patterns for the two proteins may differ (Kaufman et al., 1991). In the cerebellar cortex, GAD65 immunoreactivity was localized predominantly in axon terminals, whereas GAD67 was found in the cell bodies and proximal dendrites as well as in many axon terminals of known GABA neurons. More extensive studies have been designed to determine if these different distribution patterns for the two GAD forms are also found in most other regions of the CNS and if modifications of the immunohistochemical procedures could alter the labeling patterns for the two proteins.

A second goal was to detcrmine the rclationship between the levels of labeling for each GAD mRNA and its associated protein within the same groups of neurons. Recent in situ hybridization studies have demonstrated differences in the levels of labeling for each GAD mRNA among different populations of GABA neurons as well as differences in the levels of labeling for the two mRNAs in the same neuronal populations (Mercugliano et al., 1992b; Esclapez et al., 1993; Feldblum et al., 1993). Such findings have led to several questions. Could differences in the levels of GAD mRNA be related to corresponding differences in the levels of GAD proteins in the cell bodies? Could the levels of mRNA in the cell bodies be related to the levels of immunohistochemical labeling in the axon terminals of the corresponding neurons? Determining these relationships is important since they could reflect post-transcriptional events essential to the functional roles of these two GAD isoforms.

We have studied several brain regions with known GABA neurons in order to compare the intraneuronal distributions of the two GAD proteins and to determine the relationships between the localization of these proteins and their respective mRNAs. Each of the reagents and methods used in the studies proved to be unique in its ability to label certain GAD-containing neuronal elements or groups of GAD mRNA-containing cell bodies. Thus, complementary descriptions of G $\Lambda \mathrm{D}-$ synthesizing neurons emerged from the studies.

Preliminary reports of some of the findings have been published (Houser et al., 1989; Esclapez et al., 1991).

\section{Materials and Methods}

\section{Experimental animals and tissue preparation}

Tissue for this study was obtained from 26 adult male Sprague-Dawley rats $(150-250 \mathrm{gm})$. Twelve rats were used for immunohistochemistry (IHC), and 14 rats were used for in situ hybridization (ISH). The rats were deeply anesthetized with sodium pentobarbital $(60 \mathrm{mg} / \mathrm{kg}$, i.p.) and quickly perfused through the ascending aorta with a freshly prepared fixative solution of $4 \%$ paraformaldehyde in $0.12 \mathrm{M}$ sodium phosphate buffer ( $\mathrm{pH} 7.3)$. The rats processed for IHC received $150-250 \mathrm{ml}(1 \mathrm{ml} /$ $\mathrm{gm}$ body weight) of fixative; those processed for ISH received 450-750 $\mathrm{ml}(3 \mathrm{ml} / \mathrm{gm}$ body weight) of fixative. Following perfusion, the rats were kept for $1 \mathrm{hr}$ at $4^{\circ} \mathrm{C}$. The brains were then removed from the skull, postfixed in the same fixative for $1 \mathrm{hr}$ at room temperature (RT), rinsed in sodium phosphate buffer for $1.5 \mathrm{hr}$, and immersed in a cryoprotective solution of $20 \%$ sucrose in the same buffer overnight at $4^{\circ} \mathrm{C}$. Blocks of brain including forebrain, midbrain, olfactory bulb, and cerebellum were quickly frozen on dry ice, and $30-\mu \mathrm{m}$-thick sections were cut in a coronal or sagittal plane on a cryostat. Free-floating sections to be processed for IHC were collected and stored at $4^{\circ} \mathrm{C}$ in $0.1 \mathrm{M}$ Tris buffer $(\mathrm{pH} \mathrm{7.3)}$. Adjacent sections to be processed for ISH were collected in $0.01 \mathrm{M}$ phosphate-buffered saline, $\mathrm{pH} 7.4$ ( $1 \times$ PBS), placed sequentially into 1 $\mathrm{ml}$ tubes containing an ethylene glycol-based cryoprotective solution (Watson et al., 1986; Lu and Haber, 1992), and stored at $-20^{\circ} \mathrm{C}$ until processing. Both $1 \times$ PBS and cryoprotective solutions used for in situ hybridization were treated with $0.05 \%$ diethylpyrocarbonate and autoclaved to inactivate RNase.

\section{Immunohistochemistry}

Antibodies. The polyclonal antiserum K2, described by Kaufman et al. (1991), was used to localize GAD67. This antiserum was generated in rabbit following injection of GAD67 that was produced in a bacterial expression system from a cloned feline GAD cDNA (Kaufman et al., 1986; Kobayashi et al., 1987) and purified by sodium dodecyl sulfate polyacrylamide gel electrophoresis (Kaufman et al., 1991). This antiserum recognizes primarily rat GAD67 on Western blots (Kaufman et al., 1991).

The monoclonal antibody GAD-6, obtained by Chang and Gottlieb (1988), was used to localize GAD65. This antibody was produced by a GAD-6 hybridoma line obtained after immunization of a mouse with rat brain GAD. The culture medium from the hybridoma cells was concentrated by standard ammonium sulfate precipitation (Sambrook et al., 1989). This antibody specifically recognizes rat GAD65 on Western blots (Chang and Gottlieb, 1988; Kaufman et al., 1991).

Immunohistochemical methods. Adjacent sections were processed for GAD67 and GAD65 IHC by means of unlabeled K2 and GAD-6 antibodies, respectively, and standard avidin-biotin immunolabeling methods (Vectastain Elite ABC, Vector Laboratories, Burlingame, CA). The sections were rinsed for $30 \mathrm{~min}$ in $0.02 \mathrm{M}$ potassium phosphatebuffered saline $\left(16.5 \mathrm{mM} \mathrm{K}_{2} \mathrm{HPO}_{4}, 3.5 \mathrm{mM} \mathrm{KH}_{2} \mathrm{PO}_{4}, 150 \mathrm{mM} \mathrm{NaCl}\right.$ $\mathrm{pH} 7.4$; KPBS). Some sections were then incubated for $1 \mathrm{hr}$ at RT in the same buffer containing 3\% normal goat serum (GAD67-IHC) or normal horse serum (GAD65-IHC); other sections were incubated in the same normal serum solutions containing, in addition, $0.3 \%$ Triton $\mathrm{X}-100$. After these steps, sections processed for GAD67-IHC were incubated for $20 \mathrm{hr}$ at RT in K2 antiserum diluted 1:3000-5000 in KPBS contairing $1 \%$ normal goat serum. Sections processed for GAD65-IHC were similarly incubated in GAD-6 monoclonal antibody diluted $1: 100$ in KPBS containing 1\% normal horse serum. Following these incubations, sections were rinsed for $30 \mathrm{~min}$ in KPBS; incubated for $1 \mathrm{hr}$ at RT in biotinylated goat anti-rabbit IgG, or horse anti-mouse IgG, diluted 1:200 in KPBS containing 1\% normal goat or horse serum; rinsed in KPBS for $30 \mathrm{~min}$; and incubated for $1 \mathrm{hr}$ at RT with an avidinbiotin-peroxidase solution prepared in KPBS according to the manufacturer's recommendations. After a 30 min rinse in $0.075 \mathrm{M} \mathrm{PBS}, \mathrm{pH}$ 7.3 , sections were processed for $15 \mathrm{~min}$ in $0.06 \% 3-3^{\prime}$-diaminobenzidine $\mathrm{HCl}$ and $0.006 \% \mathrm{H}_{2} \mathrm{O}_{2}$ diluted in PBS. The sections were rinsed in PBS for $30 \mathrm{~min}$, treated in $0.05 \%$ osmium tetroxide for $30 \mathrm{sec}$, rinsed thor- 
oughly in PBS, mounted on gelatin-coated slides, dehydrated, and coverslipped with Permount.

Immunohistochemical controls. Although the $\mathrm{K} 2$ antiserum recognizes primarily GAD67, it also cross-reacts slightly with GAD65 (Rimvall and Martin, 1992). Thus, it was necessary to determine if this slight cross-reactivity affected the labeling patterns in the immunohistochemical preparations. To evaluate this possibility, some sections were incubated with $\mathrm{K} 2$ antiserum absorbed with bacterially produced rat GAD65. Additional controls included incubations of some sections with GAD-6 antibody absorbed with GAD65 and K2 antiserum absorbed with GAD67. All preabsorbed antibodies were obtained by mixing 10 $\mu \mathrm{l}$ of antibodies with $150 \mu \mathrm{l}$ of KPBS and $300 \mu \mathrm{l}$ of crude lysate of Escherichia coli expressing GAD65 or GAD67. The mixture remained at RT for $2 \mathrm{hr}$ before it was spun several times $(10 \mathrm{~min}$ each) and the supernatant collected.

The effectiveness of the absorptions was evaluated on Western blots prior to processing tissue sections with the absorbed antibodies. Proteins in whole rat brain homogenates were separated by electrophoresis on a sodium dodecyl sulfate (SDS) $10 \%$ polyacrylamide gel and electrophoretically transferred to nitrocellulose membranes according to standard protocols (Sambrook et al., 1989). Strips of these membranes were processed for immunodetection with absorbed or nonabsorbed $\mathrm{K} 2$ antiserum (diluted from 1:1000 to 1:5000) or GAD-6 antibody (diluted 1:20-100) for $1 \mathrm{hr}$ at RT, followed by the appropriate biotinylated secondary antibodies and ABC-peroxidase complex. Nonabsorbed K2 antiserum detected a strong immunoreactive band corresponding to GAD67 and a weak immunoreactive band corresponding to GAD65 (Fig. $1 A$ ). In contrast, $\mathrm{K} 2$ absorbed with GAD65 protein recognized only the GAD67 band (Fig. $1 B$ ). Nonabsorbed GAD-6 antibody recognized a single band corresponding to GAD65 (Fig. 1C). No specific staining was observed with GAD-6 absorbed with GAD65 (Fig. $1 D$ ) or with $\mathrm{K} 2$ absorbed with GAD67. These results indicated that the absorptions were complete and, of particular importance, that the absorption of K2 with GAD65 had eliminated the minor band, leaving only the major band at the location of GAD67 (Fig. 1B). The same batches of absorbed antibodies were then used for immunohistochemical processing of brain tissue, as described in the preceding section.

With the nonabsorbed $\mathrm{K} 2$ antiserum, immunoreactivity was detected in cell bodies and punctate structures corresponding to axon terminals (Fig. $2 A$ ). A virtually identical pattern of labeling was observed with the K2 antiserum absorbed with GAD65 (Fig. $2 B$ ). With the nonabsorbed GAD-6 antibody, numerous punctate structures and some cell bodies were labeled (Fig. $2 C$ ). In contrast, no labeling was evident in sections processed with the GAD-6 antibody absorbed with GAD65 (Fig. 2D). (Labeling patterns obtained with the K2 antiserum and GAD-6 antibody are discussed in detail in the Results section.)

Since the absorption of the K2 antiserum with GAD65 did not change the immunohistochemical labeling patterns in any detectable way, we concluded that $\mathrm{K} 2$ antiserum could be used as a reliable and selective marker for GAD67 in the present immunohistochemical studies. Likewise, the GAD-6 antibody was used as a specific marker for GAD65.

Additional immunohistochemical controls included incubations in preimmune rabbit serum for $\mathrm{K} 2$ and omission of the primary $\mathrm{K} 2$ antiserum or GAD-6 antibody. No labeling of neuronal cell bodies, processes, or terminals was observed in these control tissues.

\section{In situ hybridization methods}

Probe synthesis. The antisense (complementary to cellular mRNA) and control sense (identical to cellular mRNA) rat GAD67 and GAD65 probes used in this study were digoxigenin-labeled riboprobes produced by in vitro transcription of two previously described GAD cDNAs. The GAD67 cDNA (2.7 kilobases) was a subclone of the GAD67 clone isolated from a $\lambda$ gt-11 rat whole brain library using a feline GAD67 cDNA (Kaufman et al., 1986; Tillakaratne et al., 1992). The rat GAD65 cDNA ( 2.4 kilobases) was isolated from a $\lambda$ zapII rat hippocampus library (Erlander et al., 1991). GAD67 and GAD65 cDNAs, each containing the entire coding region, were subcloned into the Bluescript transcription vector (SK polylinker, Stratagene Cloning Systems, La Jolla, CA) in both orientations in order to obtain antisense and sense RNA probes. The transcription was carried out with the nonradioactive RNA labeling kit (Boehringer Mannheim, Indianapolis, IN) as described previously (Esclapez et al., 1993). Briefly, the recombinant plasmids containing the GAD67 cDNA insert were linearized with the restriction enzyme SalI and transcribed with T3 RNA polymerase. The plasmids containing the GAD65 cDNA insert were linearized with XbaI and

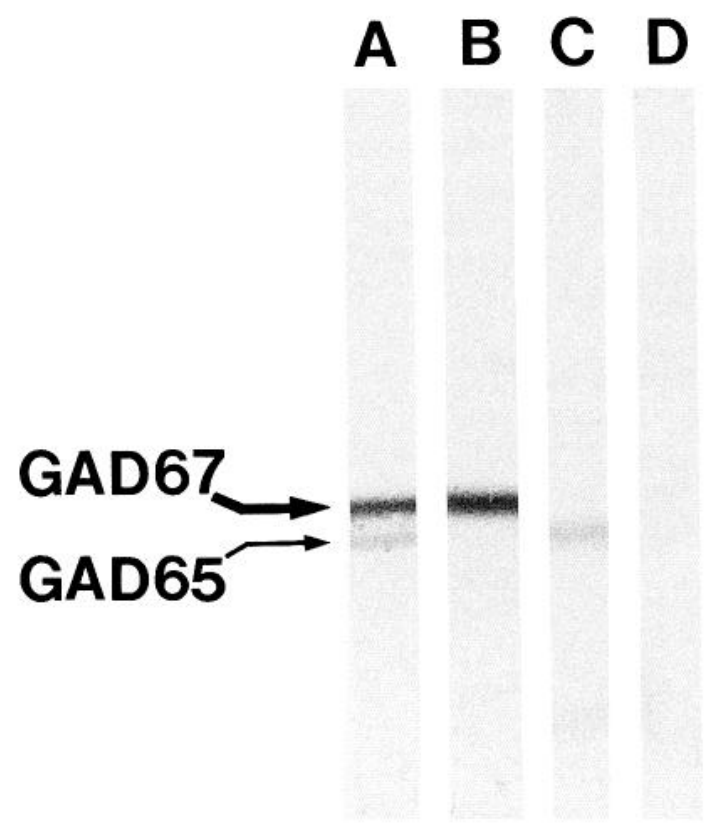

Figure 1. Western blot analysis of the effectiveness of absorption of $\mathrm{K} 2$ antiserum and GAD-6 antibody with GAD65 protein. Proteins in whole rat brain homogenate were separated by electrophoresis on a $10 \%$ SDS-polyacrylamide gel and transferred to a nitrocellulose membrane. Strips of membrane were processed for immunodetection with absorbed and nonabsorbed antibodies and avidin-biotin-peroxidase detection methods. $A, \mathrm{~K} 2$ antiserum (1:1000 dilution) recognizes a strong immunoreactive band corresponding to GAD67 (thick arrow) and a weak immunoreactive band corresponding to GAD65 (thin arrow). B, K2 antiserum absorbed with crude lysate of $E$. coli expressing rat GAD65 (1:1000 final dilution) recognizes only the GAD67 band. $C$, GAD-6 antibody (1:50 dilution) recognizes specifically one band corresponding to GAD65. D, No band is detected with GAD-6 antibody absorbed with crude lysate of $E$. coli expressing rat GAD65 (1:50 final dilution).

transcribed with T7 RNA polymerase. The transcripts labeled during the transcription with digoxigenin-11-UTP were fragmented by limited alkaline hydrolysis in order to obtain probes of approximately 160 nucleotides in length.

GAD67 and GAD65 digoxigenin-labeled riboprobes were always synthesized in parallel with the same reagents, except for the two polymerases, T3 and T7 (Boehringer Mannheim), that have comparable efficiency for the incorporation of digoxigenin-11-UTP (Hemmati-Brivanlou et al., 1990; Esclapez et al., 1993). The labeling efficiency of the antisense and sense digoxigenin-labeled probes for both GAD mRNAs was determined each time by direct immunological detection on dot blots with a nucleic acid detection kit (Boehringer Mannheim). The intensity of the signal for each probe was compared to a serial dilution of digoxigenin-labeled control RNA of known concentration. Only antisense and sense GAD67 and GAD65 probes with comparable signal intensity (comparable labeling efficiency), as determined in dot blots, were used for in situ hybridization.

Hybridization and detection. Adjacent free-floating sections, at similar locations to those processed for IHC, were processed for GAD67 and GAD65 ISH as previously described (Esclapez et al., 1993). Briefly, sections were rinsed for $30 \mathrm{~min}$ in $1 \times$ PBS and pretreated in the following solutions: $0.02 \mathrm{~N} \mathrm{HCl}$ for $10 \mathrm{~min} ; 0.01 \%$ Triton $\mathrm{X}-100$ in $1 \times$ PBS for $3 \mathrm{~min}$; and $0.25 \mu \mathrm{g} / \mathrm{ml}$ proteinase $\mathrm{K}$ in $50 \mathrm{~mm}$ Tris buffer, 5 mM EDTA, pH 7.4, for $10 \mathrm{~min}$, followed by two rinses (10 min each) in $1 \times$ PBS with $0.2 \%$ glycine. After these pretreatments, sections were incubated for $1 \mathrm{hr}$ at $\mathrm{RT}$ in a prehybridization solution containing $50 \%$ formamide, $750 \mathrm{~mm} \mathrm{NaCl}, 25 \mathrm{~mm}$ EDTA, $25 \mathrm{~mm}$ piperazine-N, $\mathrm{N}^{\prime}$-bis (2-ethanesulfonic acid) (PIPES), $0.2 \%$ SDS, $0.02 \%$ Ficoll, $0.02 \%$ polyvinylpyrrolidone, $0.02 \%$ bovine serum albumin, $250 \mu \mathrm{g} / \mathrm{ml}$ poly A, and $250 \mu \mathrm{g} / \mathrm{ml}$ salmon sperm DNA. Sections were then transferred to the hybridization solution for $16 \mathrm{hr}$ at $50^{\circ} \mathrm{C}$. This solution consisted of the prehybridization solution with the addition of $100 \mathrm{~mm}$ dithiothreitol 

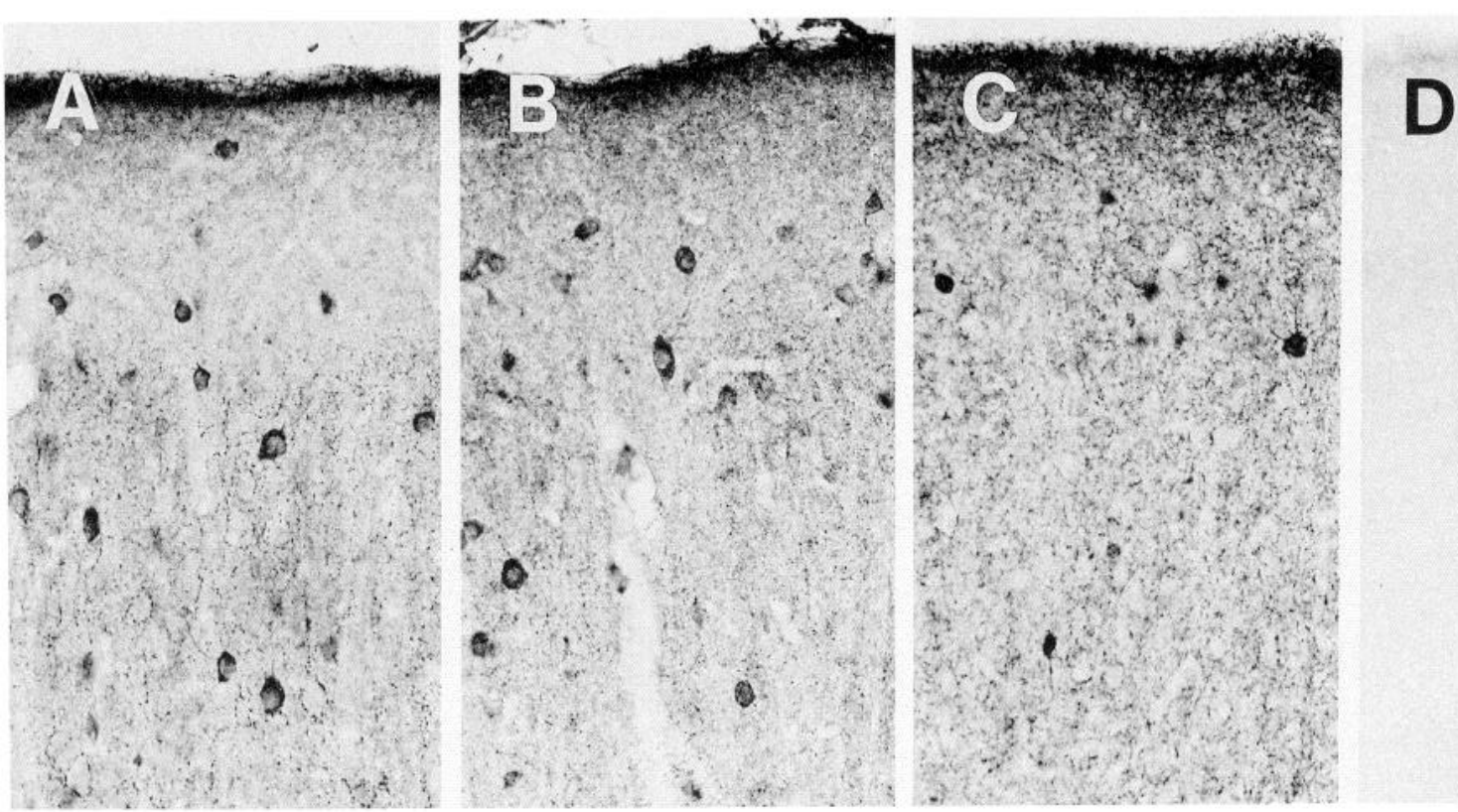

Figure 2. Immunohistochemical demonstrations of the effects of absorption of $\mathrm{K} 2$ antiserum and GAD-6 antibody with GAD65 protein in sections of cerebral cortex. $A$, With $\mathrm{K} 2$ nonabsorbed antiserum, immunoreactivity is detected in cell bodies and punctate structures corresponding to axon terminals. $B$, With $\mathrm{K} 2$ antiserum absorbed with lysate of $E$. coli expressing GAD65, the staining pattern is very similar to that obtained with the nonabsorbed $\mathrm{K} 2$ antiserum (compare $B$ to $A$ ). Both cell bodies and punctate structures are distinctly labeled. $C$, With GAD-6 antibody, numerous punctate structures and a few cell bodies are immunoreactive. $D$, With GAD-6 antibody absorbed with bacterially produced rat GAD65, no staining is detected. Scale bar, $50 \mu \mathrm{m}$.

(DTT), $4 \%$ dextran sulfate, and $0.2 \mathrm{ng} / \mu \mathrm{l}$ digoxigenin-labeled RNA probe. Following hybridization, sections were washed in a $4 \times$ saline sodium citrate solution $(1 \times$ SSC: $150 \mathrm{~mm} \mathrm{NaCl}, 60 \mathrm{~mm} \mathrm{Na}$ citrate, $\mathrm{pH} 7.0)$ containing $10 \mathrm{~mm}$ sodium thiosulfate, and treated with ribonuclease $\mathrm{A}$ $(50 \mu \mathrm{g} / \mathrm{ml}$ in $0.5 \mathrm{M} \mathrm{NaCl}, 10 \mathrm{~mm}$ sodium thiosulfate, $1 \mathrm{~mm}$ EDTA, 10 $\mathrm{mm}$ Tris- $\mathrm{HCl}$ buffer, $\mathrm{pH} 8.0$ ) for $30 \mathrm{~min}$ at $37^{\circ} \mathrm{C}$. This was followed by rinses in the same buffer for $30 \mathrm{~min}$ at RT, $2 \times \mathrm{SSC}$ with $10 \mathrm{~mm}$ sodium thiosulfate for $2 \mathrm{hr}$ at RT (low stringency condition), and $0.1 \times \mathrm{SSC}, 10$ mM sodium thiosulfate for $30 \mathrm{~min}$ at $55^{\circ} \mathrm{C}$ (high stringency condition). After these washes, sections were processed for immunodetection by means of a nucleic acid detection kit (Boehringer Mannheim). The sections were washed twice (10 min each) in $100 \mathrm{~mm}$ Tris- $\mathrm{HCl}$ buffer, $150 \mathrm{~mm} \mathrm{NaCl}, \mathrm{pH} 7.5$ (buffer 1); incubated for $1 \mathrm{hr}$ in the same buffer containing $0.5 \%$ blocking reagent and $0.3 \%$ Triton $\mathrm{X}-100$; and then incubated overnight at $4^{\circ} \mathrm{C}$ in alkaline phosphatase-conjugated sheep antibodies to digoxigenin diluted $1: 1000$ in buffer 1 containing $0.3 \%$ Triton. On the following day, the sections were incubated in a chromogen solution (for details, see Esclapez et al., 1993) until optimal staining was achieved for each GAD mRNA. Optimal staining was defined as a maximum number of specifically stained neurons (maximum sensitivity) with a low background of general tissue staining and no nonspecific staining of cell bodies. For a probe concentration of 0.2 $\mathrm{ng} / \mu \mathrm{l}$ (the concentration chosen for these experiments), the optimal color reaction times for the majority of brain regions were 3-4 hr when processed with the GAD67 probe and 5-6 hr when processed with the GAD65 probe. The sections were then mounted on gelatin-coated slides, dried, and coverslipped in an aqueous mounting medium (Crystal/Mount, Biomeda, Foster City, CA).

Specificity of probes and in situ hybridization methods. Previous work has established that rat GAD67 and GAD65 cDNAs, which share $65 \%$ nucleotide sequence identity within the coding region, hybridize selectively to two different cellular mRNAs of 3.7 and 5.7 kilobases, respectively, and do not cross-hybridize with the alternate mRNA at high stringency (Erlander et al., 1991). A lack of cross-hybridization for the two cRNA probes was also demonstrated on slot blots with the present nonradioactive labeling methods and the same conditions of hybridization and stringency that were used on tissue (Esclapez et al., 1993). The specificity of the hybridization reaction was checked by processing some sections as described above but using labeled sense probes instead of antisense probes. No staining was observed in these conditions.

\section{Results}

\section{Characteristics of GAD67 and GAD65 localization}

In most brain regions, including the cerebral cortex, both immunoreactive cell bodies and punctate structures (presumptive axon terminals) were observed in sections processed with GAD67-specific antiserum K2 (Fig. $3 A, C$ ), as well as in sections processed with GAD65-specific antibody, GAD-6 (Fig. 3B,D). However, the population of cell bodies that were immunoreactive for GAD67 was larger than the population of cell bodies that was immunoreactive for GAD65 (compare Fig. $3 A, B$ ). Similarly, the cell bodies of most groups of GABA neurons in the brain were labeled for GAD67, whereas only some of these GABA neurons were consistently labeled for GAD65. In contrast, the density (quantity) of GAD65-immunoreactive axon terminals was higher than the density of GAD67-immunoreactive terminals, and this was characterized at low magnification by a heavier labeling, particularly of the superficial cortical layers, for GAD65 than for GAD67 (compare Fig. 3A,B). At higher magnification, this difference in the density of terminals was evident for the terminals scattered within the neuropil as well as for those surrounding nonlabeled or labeled cell bodies and proximal dendrites (compare Fig. $3 C, D$ ). These patterns and those discussed below were observed when no detergent (Triton $\mathrm{X}-100$ ) was used in the immunohistochemical processing.

In a few brain regions, such as the reticular nucleus of the thalamus, the neuronal population that was immunoreactive for GAD67 was similar to the population that was immunoreactive for GAD65. In the reticular nucleus, essentially all neurons exhibited strong and comparable cytoplasmic labeling of the cell bodies for both GADs (Fig. 4A,B). However, some features of the labeling for the two GADs were slightly different; in many GAD67-immunoreactive neurons, substantial labeling extend- 

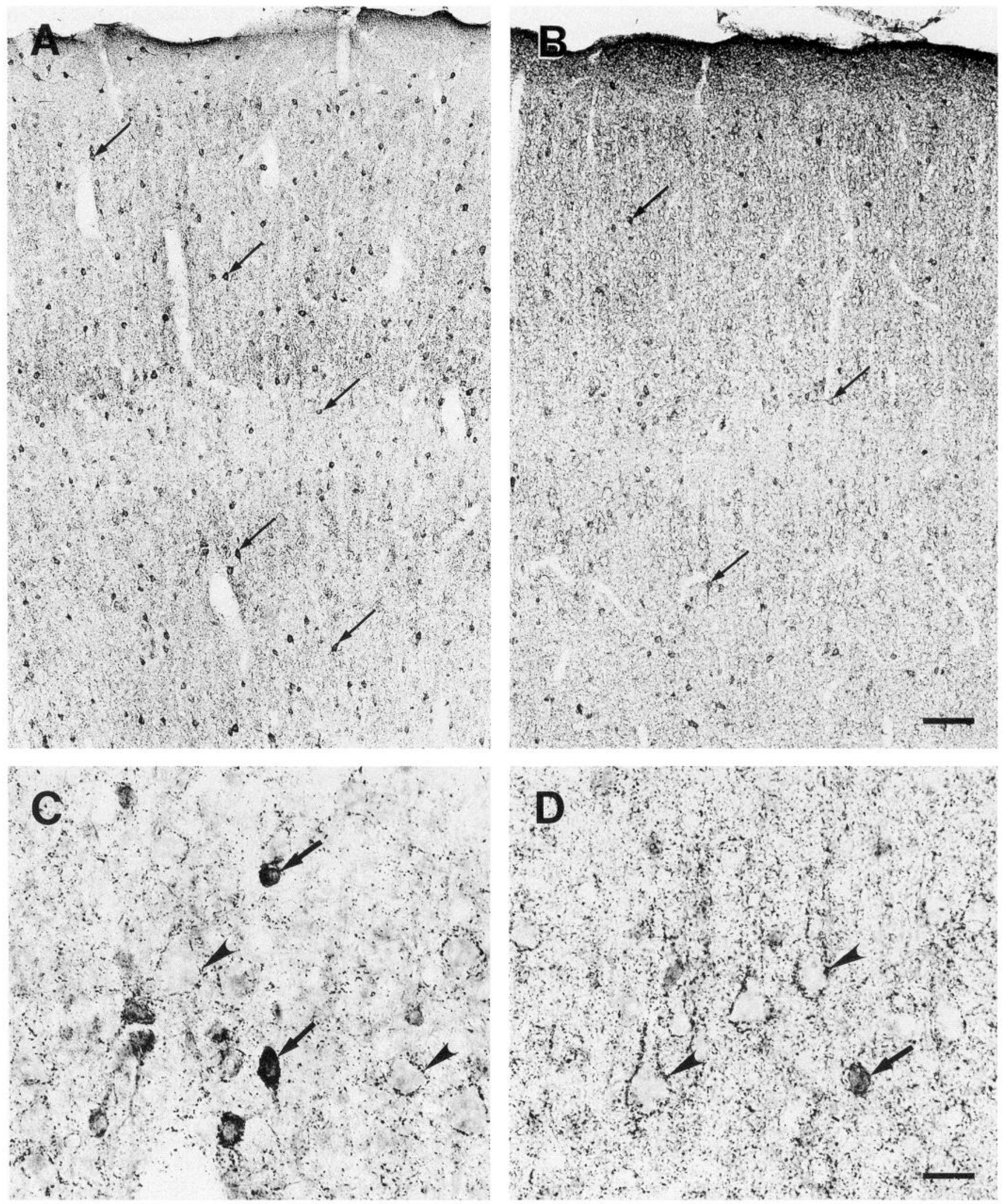

Figure 3. Immunohistochemical localization of GAD67 and GAD65 in coronal sections of parietal cortex. A, With K2 antiserum, which recognizes primarily GAD67, immunoreactivity is present in numerous cell bodies (arrows) of nonpyramidal neurons as well as in punctate structures (presumptive axon terminals) distributed in all cortical layers. $B$, With GAD-6 antibody, which specifically recognizes GAD65, high concentrations of immunoreactive puncta are primarily observed, but some immunoreactive cell bodies are also detected in all cortical layers (arrows). These cell bodies are less numerous than those observed with $\mathrm{K} 2$ antiserum (compare $B$ to $A$ ). $C$, GAD67-labeled terminals are scattered within the neuropil and outline unlabeled somata (arrowheads). Several GAD67-containing cell bodies are observed (arrows). D, GAD65-labeled terminals are present within the neuropil or surrounding cell bodies and apical dendrites of many unlabeled pyramidal neurons (arrowheads). The density (quantity) of these terminals is higher than that of GAD67-labeled terminals (compare $D$ to $C$ ). Only a few labeled cell bodies are observed (arrow). Scale bars: $A$ and $B, 100 \mu \mathrm{m} ; C$ and $D, 25 \mu \mathrm{m}$. 

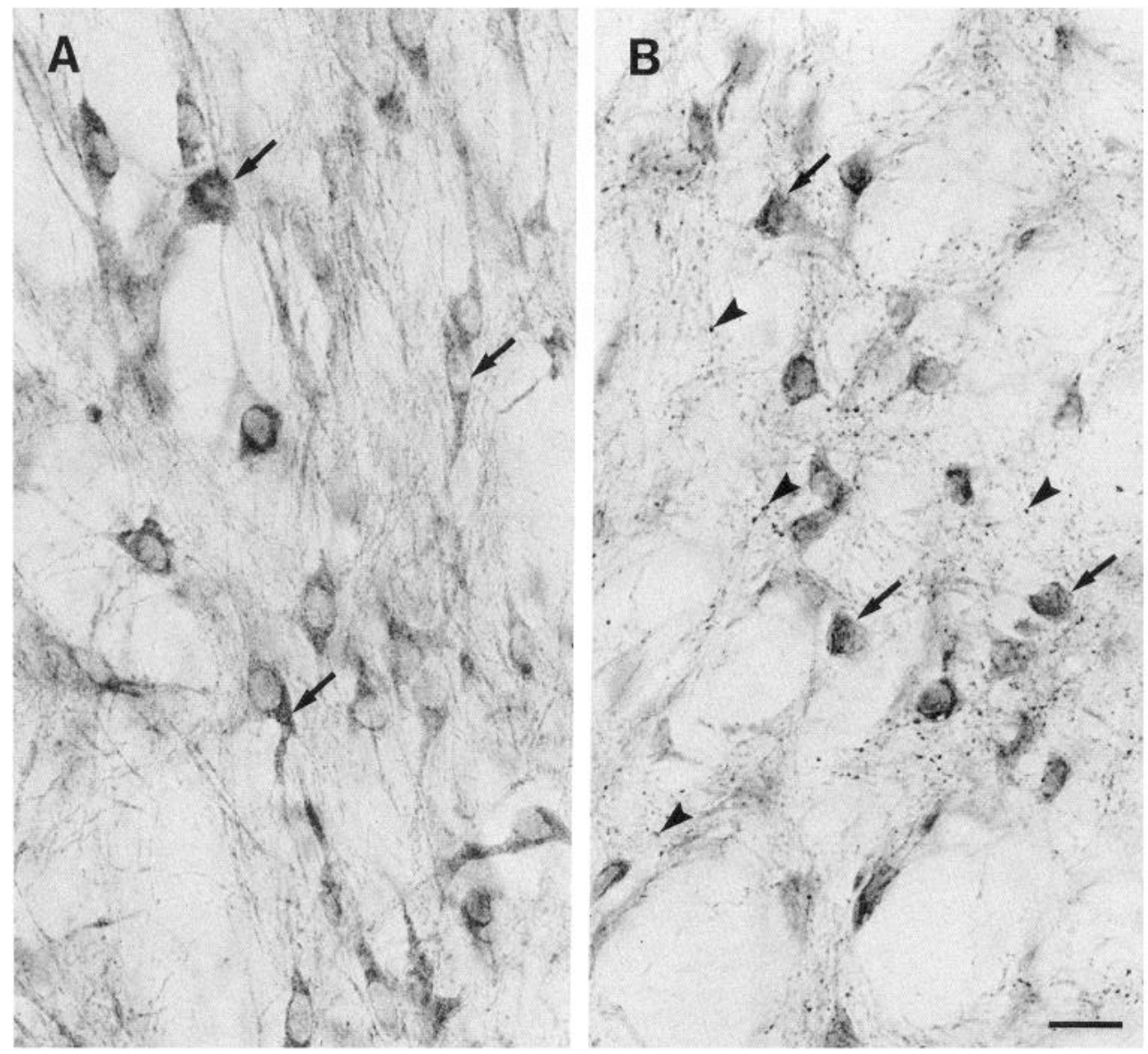

Figure 4. Comparison of labeling for GAD67 and GAD65 in coronal sections of the reticular nucleus of the thalamus. $A$, With $\mathrm{K} 2$ antiserum, strong cytoplasmic labeling is present in the cell bodies and proximal dendritic processes of many medium to large neurons (arrows). Relatively few GAD67-labeled terminals are detected. $B$, With GAD-6 antibody, comparable strong cytoplasmic labeling is present in the cell bodies of these neurons, but in most of these neurons the labeling is limited to the cell bodies (arrows). Only a few dendritic profiles are labeled. Many GAD65-containing terminals are observed in the neuropil (arrowheads). Scale bar, $25 \mu \mathrm{m}$ for $A$ and $B$.

ed into proximal dendritic profiles (Fig. $4 A$ ), whereas in most GAD65-immunoreactive neurons, the staining was confined to the cell bodies (Fig. 4B). Furthermore, relatively few GAD67immunoreactive terminals were detected in this nucleus, whereas GAD65-immunoreactive terminals were quite numerous (compare Fig. $4 A, B$ ).

The olfactory bulb and cerebellar cortex provided examples of similar as well as different patterns of cell body labeling for the two GADs among several well-known subclasses of GABA neurons. In the olfactory bulb, all known GABA cell types were labeled for GAD67. These neurons included the periglomerular cells (Fig. $5 A$ ), the granule cells (Fig. $5 C$ ), and small neurons scattered within the external plexiform layer. All of these neurons exhibited moderate to strong labeling of the cell bodies. Among these subclasses of GABA neurons, the periglomerular cells were the only neurons strongly labeled for GAD65 (Fig. $5 B$ ). The vast majority of the granule cells was not labeled for GAD65, except for a few cells that were located primarily in the outer part of the granule cell layer (Fig. $5 D$ ). The staining of these GAD65-immunoreactive granule cells was weak compared to the staining of the periglomerular cells in the same section (compare Fig. $5 B, D$ ).

In the cerebellar cortex, the cell bodies of all classes of GABA neurons were clearly labeled for GAD67 (Fig. 6A). The Purkinje cells showed strong labeling of the cell bodies and main dendritic arborizations. The stellate and basket cells in the molecular layer exhibited labeling of the thin cytoplasmic ring of the cell bodies. In the granule cell layer, numerous Golgi cells were stained. These different subclasses of GABA neurons were also labeled for GAD65 (Fig. 6B), but the labeling of the cell bodies was quite light. In addition, only a part of the total population was labeled. This was particularly obvious for the stellate and basket cells in the molecular layer where only a few GAD65-labeled cell bodies were observed. The somata of the Golgi cells were more consistently labeled for GAD65 than other GABA neurons in the cerebellar cortex.

In addition to containing the cell bodies of several groups of GABA neurons, the cerebellum was also rich in GAD-containing terminals. Even though terminal labeling was observed for both GAD67 and GAD65 in all layers of the cerebellar cortex, the features of the terminal staining were different for each of the two GADs. The density of GAD65-containing terminals, scattered within the neuropil or surrounding cell bodies and dendritic arborization of the Purkinje cells, was higher than the density of GAD67-containing terminals (compare Fig. 6A,B). Furthermore, the size of GAD65-immunoreactive terminals frequently appeared larger than that of GAD67-labeled terminals.

In order to determine if the inclusion of a detergent in the immunohistochemical processing would affect the localization patterns, Triton X-100 was included in the initial normal serum incubation, and the labeling for the two GADs with and without Triton was compared. In these experimental conditions, a decrease in cell body staining and an increase of terminal densities (quantity) were observed in all brain regions. The cerebellum provide an example of such results. When Triton was included in the immunohistochemical processing, the staining of neuronal cell bodies was substantially reduced. The cell bodies of the Purkinje and Golgi cells were only slightly labeled for GAD67, 
Figure 5. Comparison of labeling for GAD67 and GAD65 in sagittal sections of olfactory bulb. $A$, A large number of periglomerular cell bodies (arrows) are moderately labeled for GAD67. $B$, In an adjacent section, many of the periglomerular cell bodies (arrows) exhibit strong labeling for GAD65. $C$, In the same section as $A$, cell bodies of granule cells (arrowheads) are strongly labeled for GAD67. D, A few granule cells are labeled for GAD65 (arrowheads), but these GAD65-immunoreactive granule cells are present primarily in the external part of the granule cell layer $(G)$ at the border with the plexiform layer $(P L)$. The intensity of the labeling is lighter than that of the periglomerular cells observed in the same section $(B)$. Scale bar, $20 \mu \mathrm{m}$ for $A-D$.
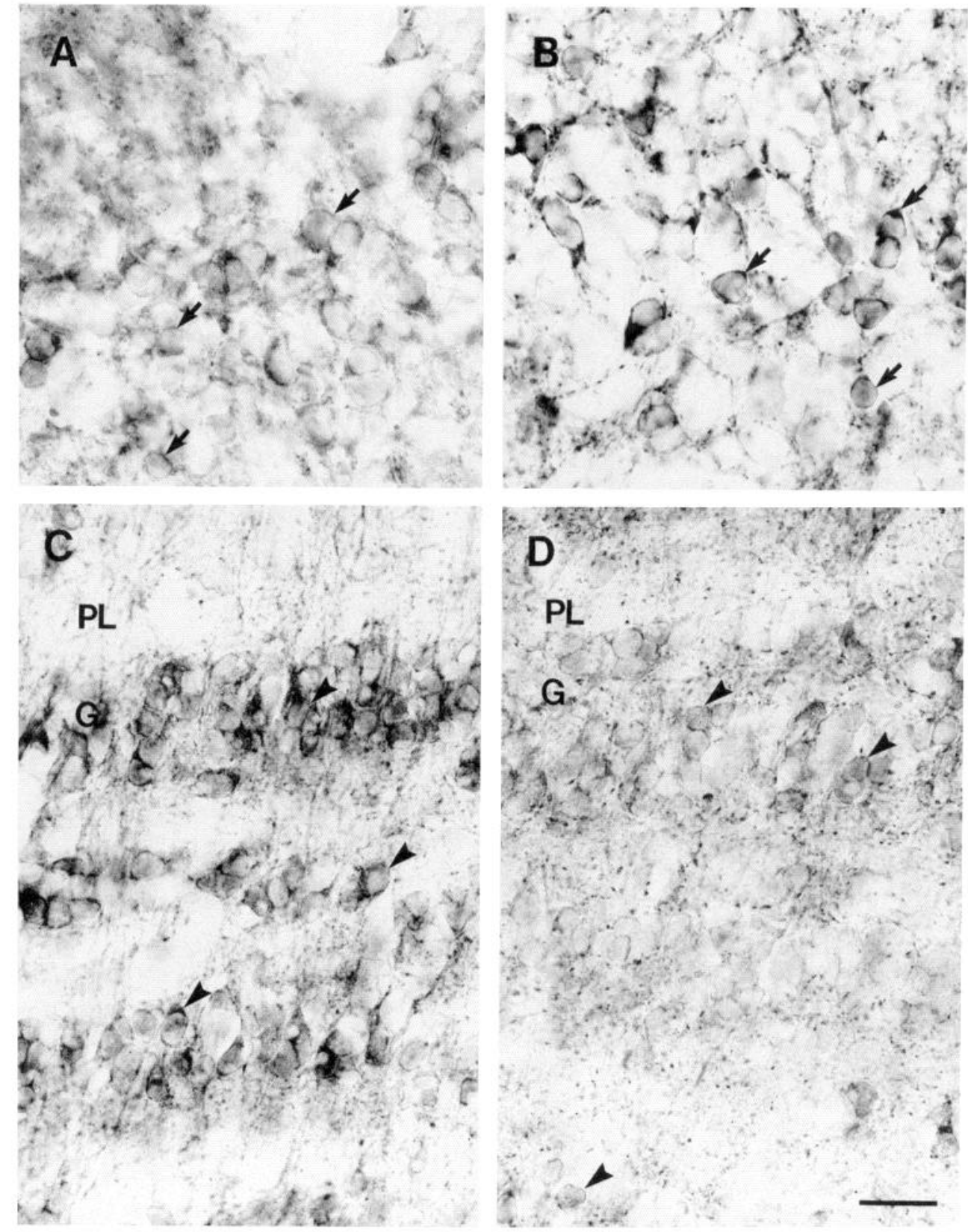

and the cell bodies of many stellate and basket cells were no longer observed (Fig. $6 \mathrm{C}$ ). Virtually no cell bodies were labeled for GAD65 (Fig. 6D). With the use of Triton, terminal labeling was increased for both GADs. In Triton-treated sections, GAD65-containing terminals were extremely numerous, and the densities of terminals in all layers were substantially higher than those in sections processed for GAD65 without detergent (compare Fig. 6B,D). The density of GAD67-containing terminals was now similar to the density of GAD65-immunoreactive terminals obtained in the absence of Triton (compare

Figure 6. Comparison of labeling for GAD67 and GAD65 in parasagittal sections of cerebellar cortex in the absence $(A, B)$ or presence $(C, D)$ of Triton $\mathrm{X}-100$ in the immunohistochemical processing. $A$, With $\mathrm{K} 2$ antiserum, in the absence of Triton, distinct labeling of the cell bodies and proximal dendrites of the Purkinje cells $(P)$ is observed. Somata of stellate/basket cells (thick arrows) in the molecular layer $(M)$ and of the Golgi cells (arrowhead) in the granule cell layer $(G)$ show moderate labeling. GAD67-containing terminals (thin arrows) are present in all cerebellar layers. $B$, With GAD-6 antibody in the absence of Triton, light cytoplasmic staining is present in the cell bodies of the Purkinje cells. Only a few stellate/ basket cells (thick arrow) are labeled. Numerous GAD65-immunoreactive terminals (thin arrows) are observed around the cell bodies and proximal dendrites of the Purkinje cells and in the neuropil of all the layers. $C$, With $\mathrm{K} 2$ antiserum, in the presence of Triton, weak staining of the cell bodies of the Purkinje cells is observed. More GAD67-immunoreactive terminals are present in the molecular $(M)$ and granule cell $(G)$ layers than in sections processed without Triton (compare $C$ to $A$ ). The concentrations of terminals are relatively similar to those of GAD65-labeled terminals in the absence of Triton (compare $C$ to $B$ ). $D$, With GAD-6 antibody in the presence of Triton, no cell body labeling is detected. Extremely large numbers of terminals (arrows) and axonal profiles are now observed around the cell bodies and dendritic arborizations of the Purkinje cells and in all cerebellar layers. Scale bar, $25 \mu \mathrm{m}$ for $A-D$. 

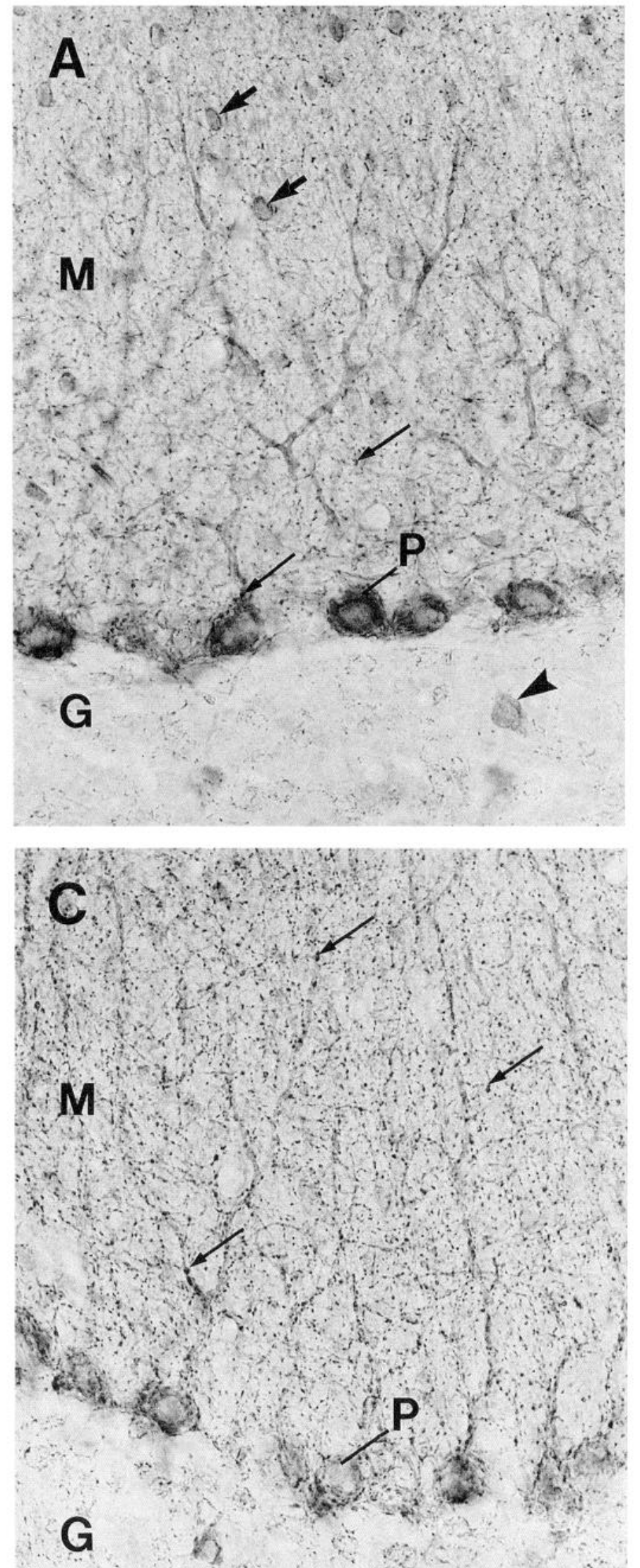

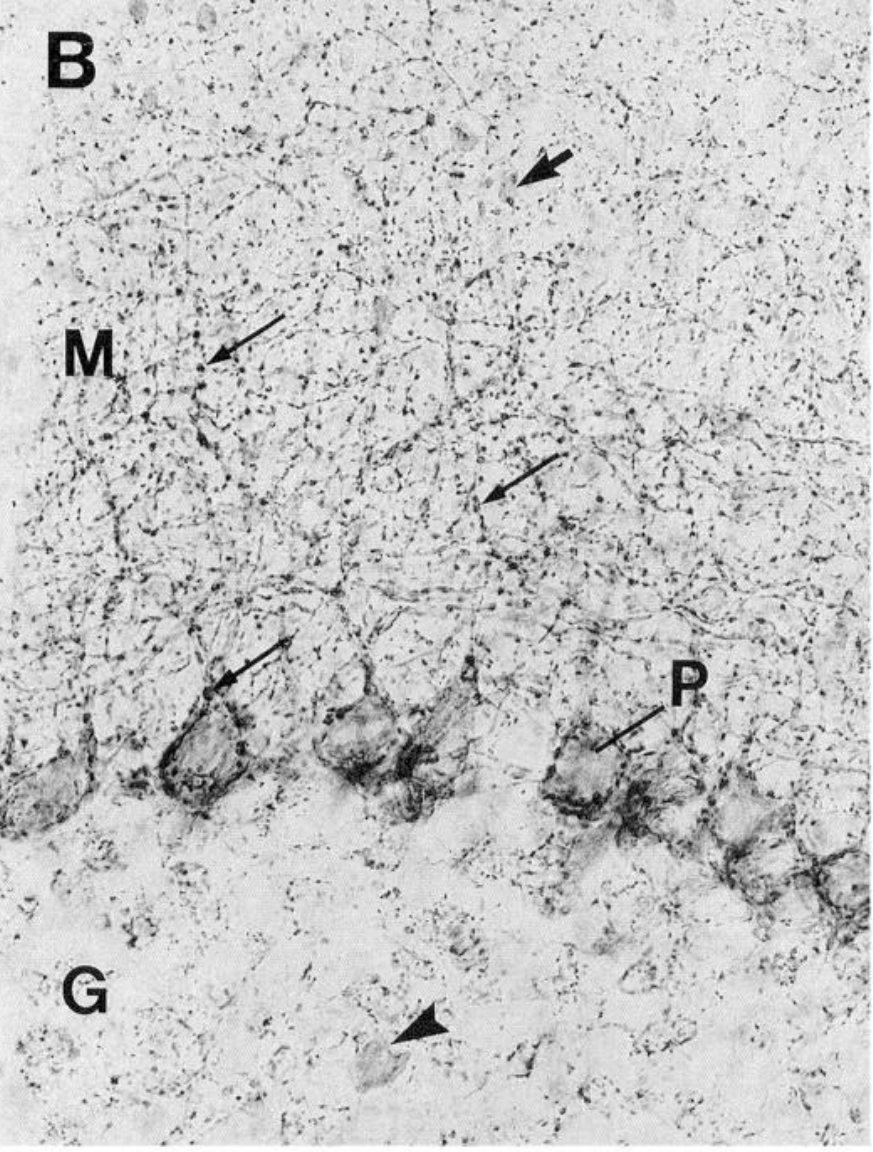

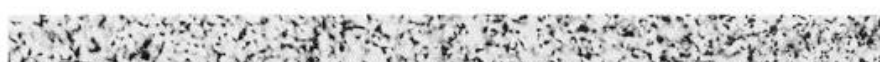

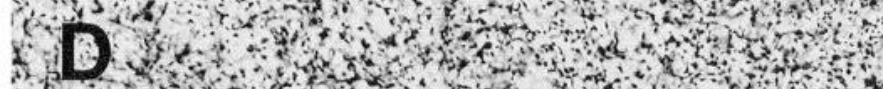

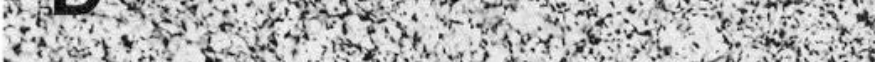

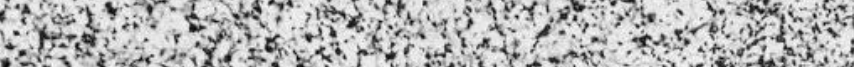

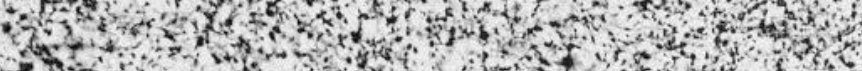

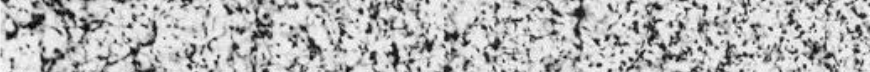

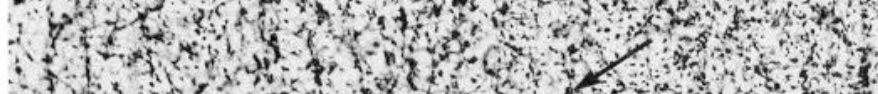

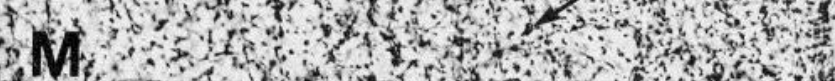

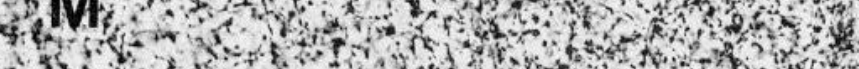

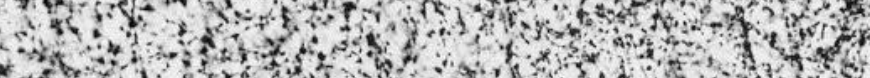

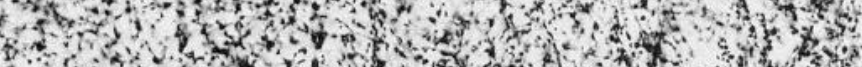

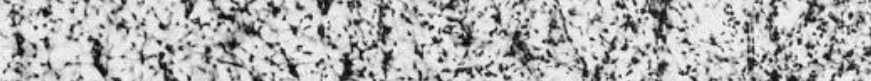
हn

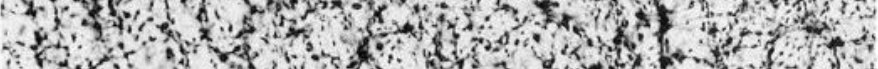

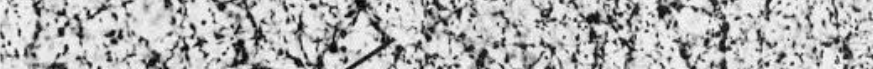

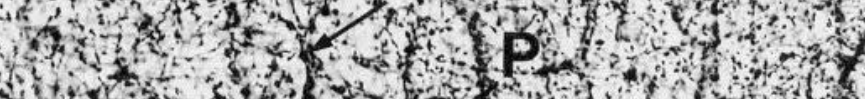

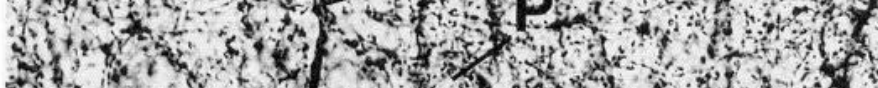

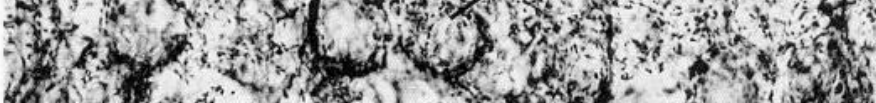

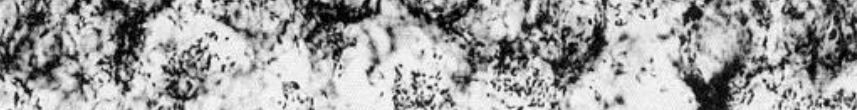

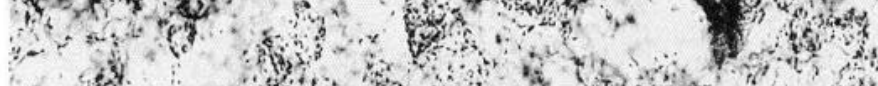

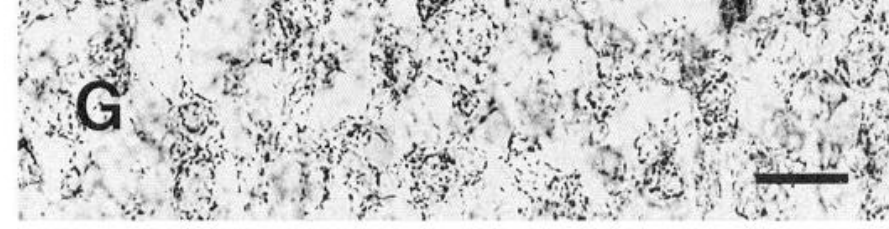




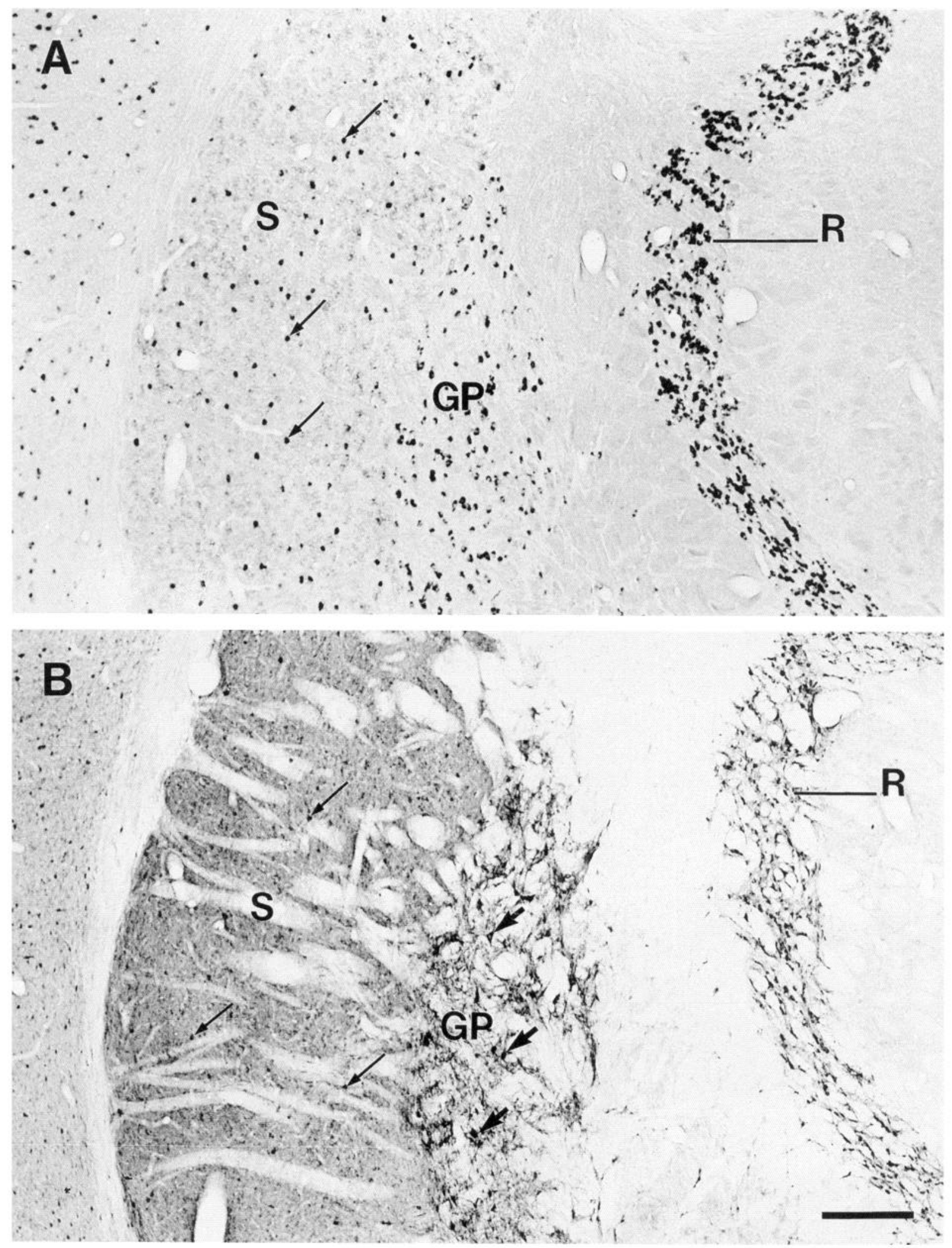

Figure 7. Comparison of labeling for GAD67 and its mRNA in coronal sections of basal ganglia. A, A small population of neurons dispersed throughout the striatum $(S)$ are heavily labeled for GAD67 mRNA (arrows), whereas the majority of the neurons in this nucleus are lightly labeled for GAD67 mRNA. Many neurons in the globus pallidus $(G P)$ are strongly labeled. Both populations of strongly labeled neurons in the striatum and globus pallidus exhibit a similar intensity of staining to that of the GAD67-containing neurons in the reticular nucleus of the thalamus ( $R$ ). $B$, In the striatum of an immunolabeled section, a few cell bodies (thin arrows) are readily labeled for GAD67 and are distributed among a larger number of weakly labeled neurons. In the globus pallidus, despite a high concentration of terminals, some GAD67-containing neurons (thick arrows) are clearly observed. In these two nuclei of the basal ganglia, similar patterns of cell body staining are observed for GAD67 with immunohistochemical methods and for GAD67 mRNA with in situ hybridization methods (compare $B$ to $A$ ). Scale bar, $300 \mu$ m for $A$ and $B$. 


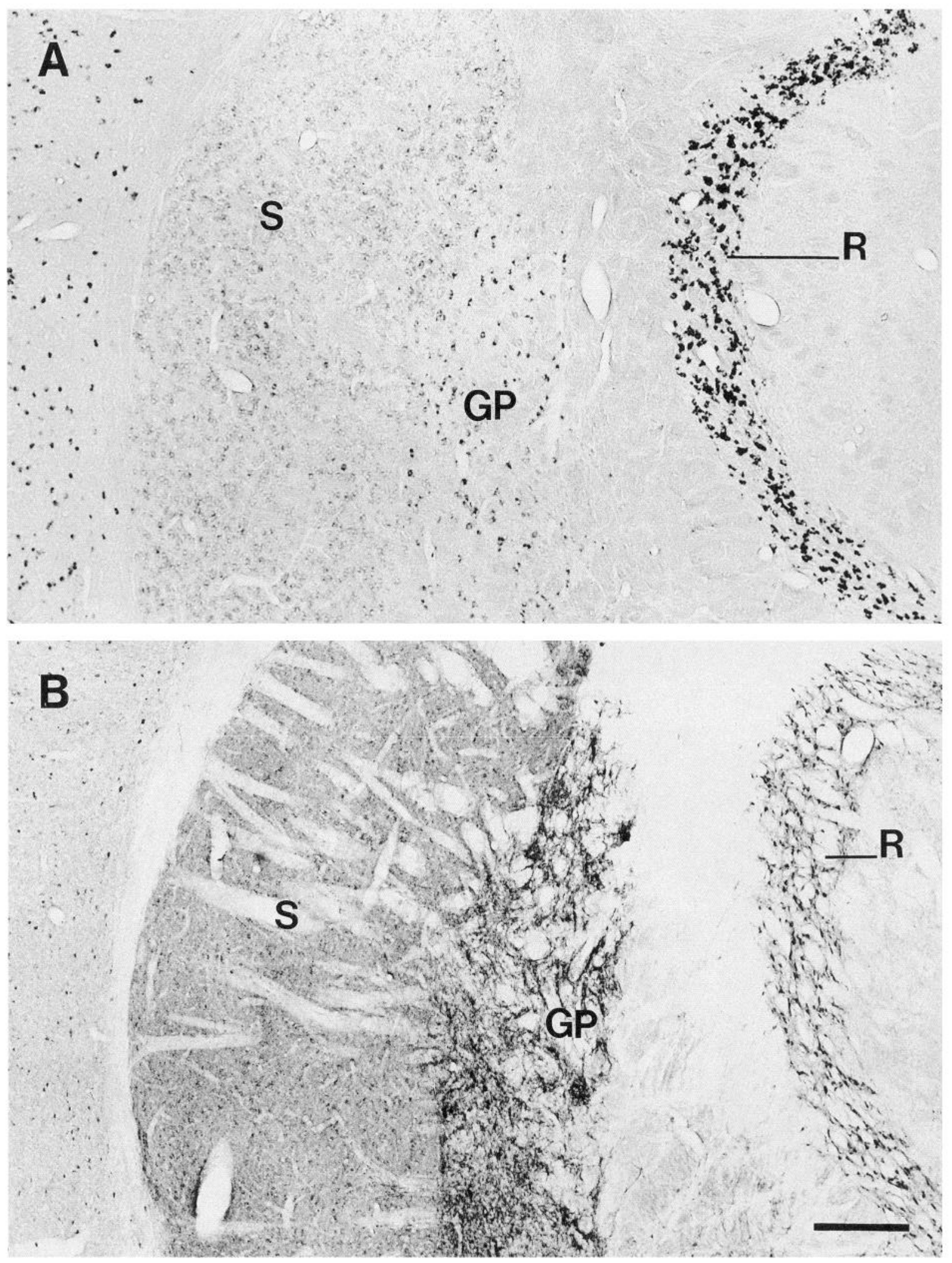

Figure 8. Comparison of labeling for GAD65 and its mRNA in coronal sections of basal ganglia. $A$, In the striatum $(S)$, the vast majority of neurons are lightly labeled for GAD65 mRNA. The neurons of the globus pallidus $(G P)$ exhibit moderate labeling. The light to moderate labeling of neurons in these two nuclei of the basal ganglia contrasts with the heavy labeling of GAD65-containing neurons in the reticular nucleus $(R)$. $B$, In the striatum, numerous cell bodies are lightly to moderately labeled for GAD65, and thus the pattern of GAD65-labeled cell bodies is similar to that of GAD65 mRNA-containing neurons (compare $B$ to $A$ ). No cell body labeling is evident in the globus pallidus, even at high magnification, but large numbers of terminals are present. Scale bar, $300 \mu \mathrm{m}$ for $A$ and $B$. 

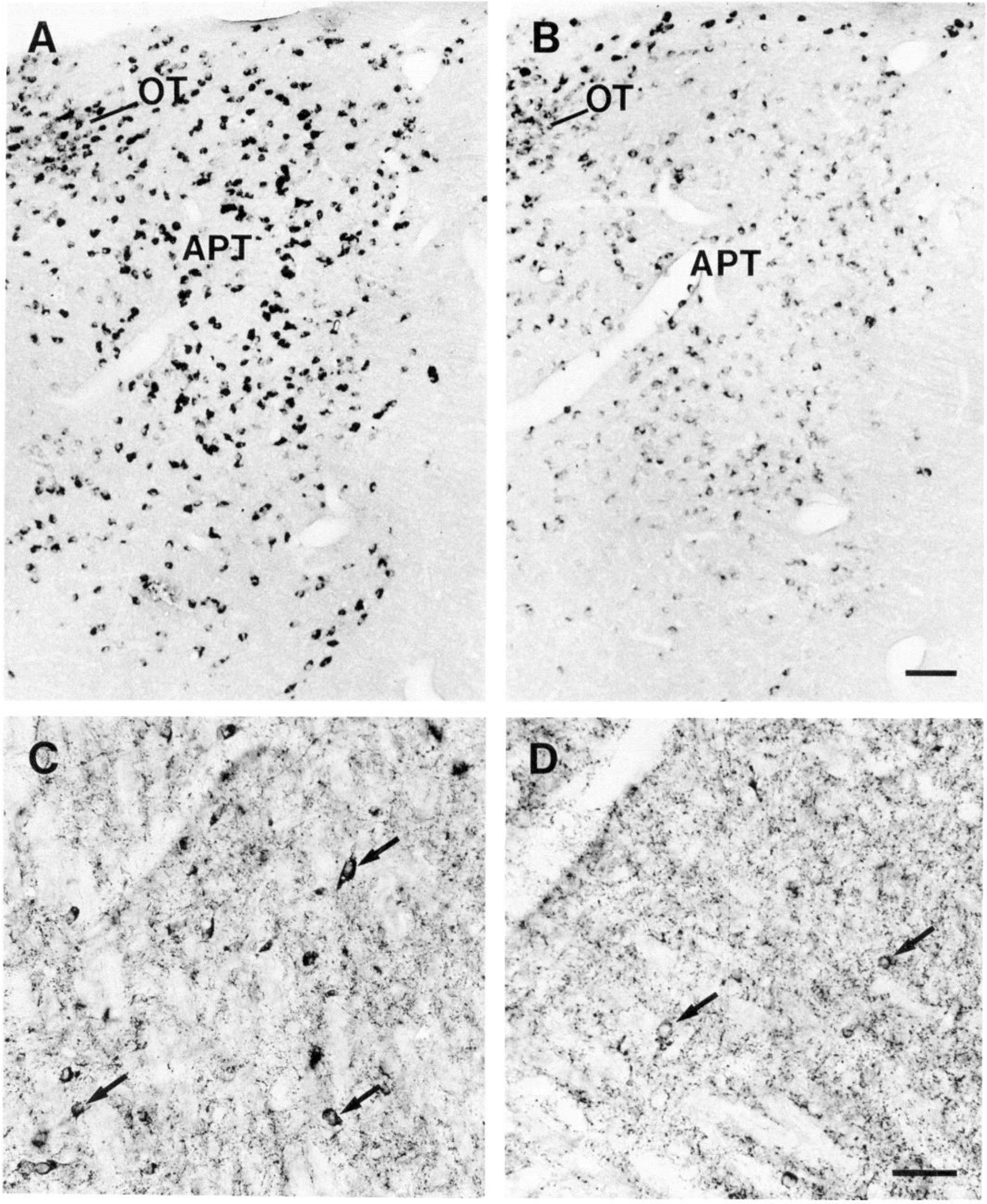

Figure 9. Comparison of labeling for the two GADs and their mRNAs in the anterior pretectal nucleus ( $A P T)$. $A, \mathrm{~A}$ large number of neurons are strongly labeled for GAD67 mRNA. B, A similar group of neurons is labeled for GAD65 mRNA but the intensity of the labeling is lighter than that observed for GAD67 mRNA-containing neurons (compare $B$ to $A$ ). The light intensity of GAD65 mRNA-labeled neurons in this nucleus contrasts with the strong labeling of the neurons in the adjacent nucleus of the optic tract $(O T)$. $C$, Many GAD67-immunoreactive cell bodies (arrows) and terminals are observed in the APT. D, Only a few GAD65-labeled cell bodies (arrows) are detected, and these neurons exhibit weak immunoreactive labeling. In contrast numerous terminals are labeled for GAD65. Scale bars: $A$ and $B, 100 \mu \mathrm{m} ; C$ and $D, 50 \mu \mathrm{m}$. 

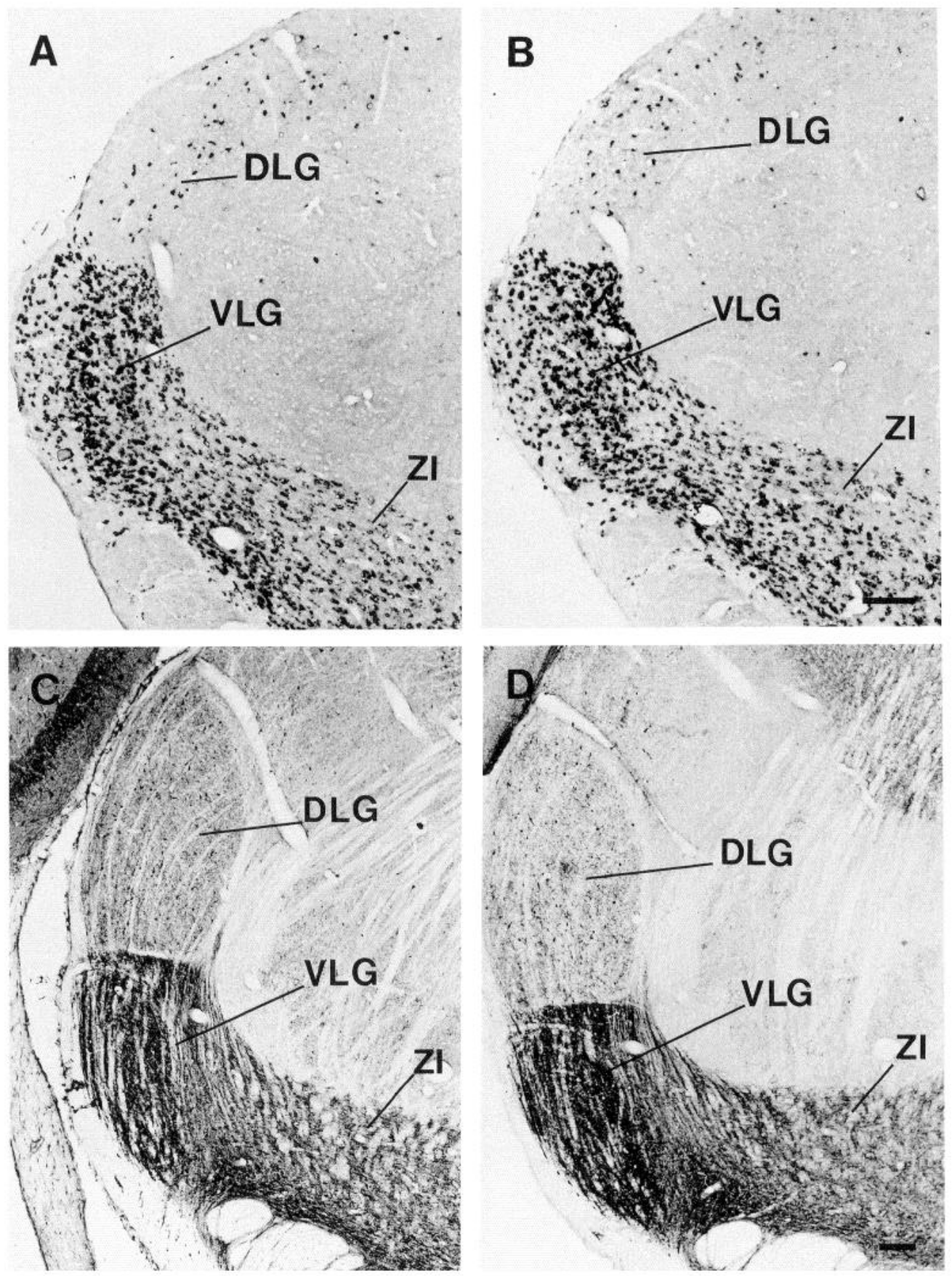

Figure 10. Comparison of labeling for the two GADs and their mRNA in the ventral $(V L G)$ and dorsal $(D L G)$ lateral geniculate nuclei and zona incerta $(Z I)$. $A$ and $B$, Numerous neurons are strongly to moderately labeled for GAD 67 mRNA $(A)$ and GAD65 mRNA $(B)$ in the VLG and ZI. The intensity of labeling is comparable for the two GAD mRNAs. Some GAD67 and GAD65 mRNA-labeled neurons are also observed in the DLG. $C$ and $D$, With the immunohistochemical methods for GAD67 (C) and GAD65 (D), very high concentrations of labeled terminals are present in the VLG and ZI, and cell body labeling is very difficult to detect. In contrast, in the DLG, cell bodies labeled for GAD67 $(C)$ as well as for GAD65 $(D)$ are clearly observed. This nucleus contains only a moderate concentration of terminals. Scale bars, 150 $\mu \mathrm{m}$ for $A-D$.
Fig. $6 B, C$ ), but never reached that of the GAD65-labeled terminals with Triton (compare Fig. $6 C, D$ ).

\section{Comparative localization of GADs and GAD mRNAs}

Cell body labeling. The present nonradioactive in situ hybridization methods allowed a clear visualization of neurons labeled for each GAD mRNA. The cellular resolution of these methods was similar to that obtained with immunohistochemical methods, and thus the sizes and shapes of the GAD mRNA-labeled cell bodies could be determined. In addition, differences in the intensity of labeling (heavily and lightly labeled neurons), which reflect differences in the mRNA concentrations, were observed among different groups of GABA neurons for each GAD mRNA. The intensity of labeling was also frequently different for the two GAD mRNAs. For most brain regions, longer times in the color reaction were required to obtain optimal staining for GAD65 mRNA than for GAD67 mRNA, suggesting that the neurons contained lower levels of GAD65 mRNA than GAD67 mRNA. Differences and similarities in the intensity of labeling for the two GAD mRNAs and their labeling patterns (distribution of heavily and lightly labeled neurons) have been described in detail previously for several brain regions (Esclapez et al., 1993). In the present study, we compare the patterns of labeling for the two GAD proteins with those for their respective GAD mRNAs.

In many brain regions, the patterns of cell body labeling obtained for the GAD proteins with immunohistochemical methods were similar to the patterns of labeling for the GAD mRNAs obtained with in situ hybridization methods. The reticular nucleus of the thalamus is an example of a brain region in which 
Figure 11. Comparison between cell body and terminal labeling of the Purkinje cells for the two GADs in parasagittal sections of cerebellum, with in situ hybridization methods and immunohistochemical methods, respectively. $A$, In the cerebellar cortex, the cell bodies of Purkinje cells $(P)$ are strongly labeled for GAD67 mRNA. The thin rim of cytoplasm of the stellate cells (arrows) in the molecular layer $(M)$ as well as the Golgi cells (arrowheads) in the granule cell layer $(G)$ are strongly labeled for GAD67 mRNA. $B$, In contrast, the Purkinje cells exhibit light labeling for GAD65 mRNA. Weak labeling for GAD65 mRNA is present in the stellate cells (arrows), whereas the Golgi cells (arrowhead) exhibit strong labeling. $C$, Numerous terminals are strongly labeled for GAD67 and outline cell bodies and the main dendrites of large unlabeled neurons (arrows) in the deep cerebellar nuclei to which the Purkinje cells project. $D$, A similar pattern of terminal labeling is observed for GAD65. These terminals (arrows) are often large and very strongly labele $\mathrm{d}$. Scale bars, $25 \mu \mathrm{m}$ for $A-D$.
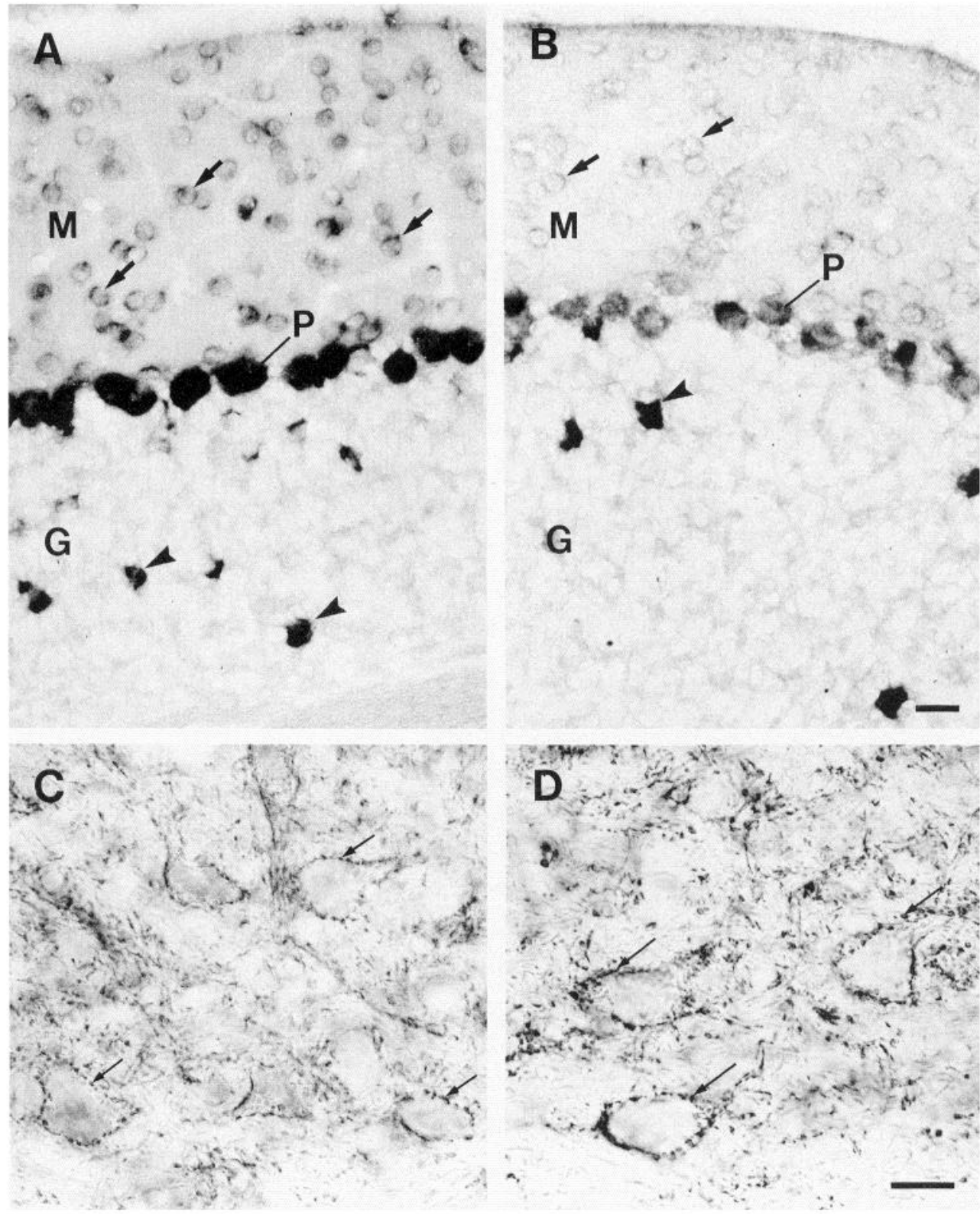

G

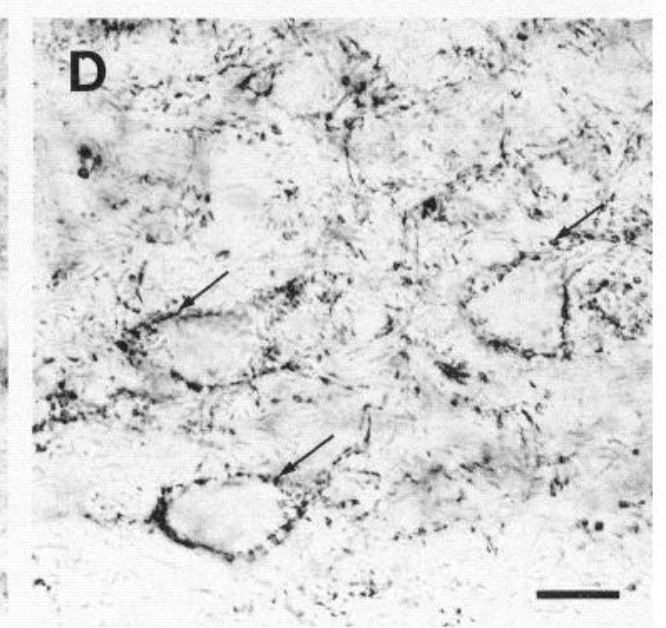

there was strong labeling of the cell bodies for both GAD mRNAs and their related proteins. Virtually all neurons were heavily labeled for GAD67 mRNA (Fig. 7A), and strong immunostaining of the cell bodies was also observed for GAD67 (Fig. 7B). Similarly, all of these neurons were strongly labeled for GAD65 mRNA (Fig. 8A) and clearly labeled for GAD65 (Fig. 8B). In addition, the intensity of labeling for GAD65 mRNA was similar to that for GAD67 mRNA and was observed after the same length of time in the color reaction. The immunohistochemical labeling of the cell bodies for GAD65 and GAD67 was also comparable, as described in the previous section.

Among the basal ganglia, the striatum illustrated similar patterns of cell body labeling with immunohistochemical and in situ hybridization methods. However, the patterns of labeling observed for GAD67 and its mRNA were different from those observed for GAD65 and its mRNA. The patterns of labeling for GAD67 mRNA and GAD67 were heterogeneous, as has been described previously (Chesselet et al., 1987; Gonzales et al., 1991; Mercugliano et al., 1992b; Esclapez et al., 1993; Feldblum et al., 1993). A small population of neurons dispersed throughout the striatum was heavily labeled for GAD67 mRNA, while the majority of striatal neurons was more lightly labeled (Fig. 7A). A similar pattern was observed in sections processed with GAD67 immunohistochemical methods and consisted of a few strongly labeled cell bodies distributed among a large number of small neurons that exhibited lighter labeling (Fig. $7 B$ ). On the other hand, the patterns of labeling for GAD65 and its mRNA were more homogeneous. A large population of cell bodies was labeled for GAD65 mRNA (Fig. $8 A$ ); this labeling was light when compared to the labeling of GAD65 mRNAcontaining neurons in the reticular nucleus in the same section. Heavily labeled striatal neurons such as those labeled for GAD67 mRNA were not observed. The cell bodies of numerous neurons were labeled for GAD65, and the pattern of cell body labeling was homogeneous and thus similar to that observed with in situ hybridization methods. The cell body labeling was light but 

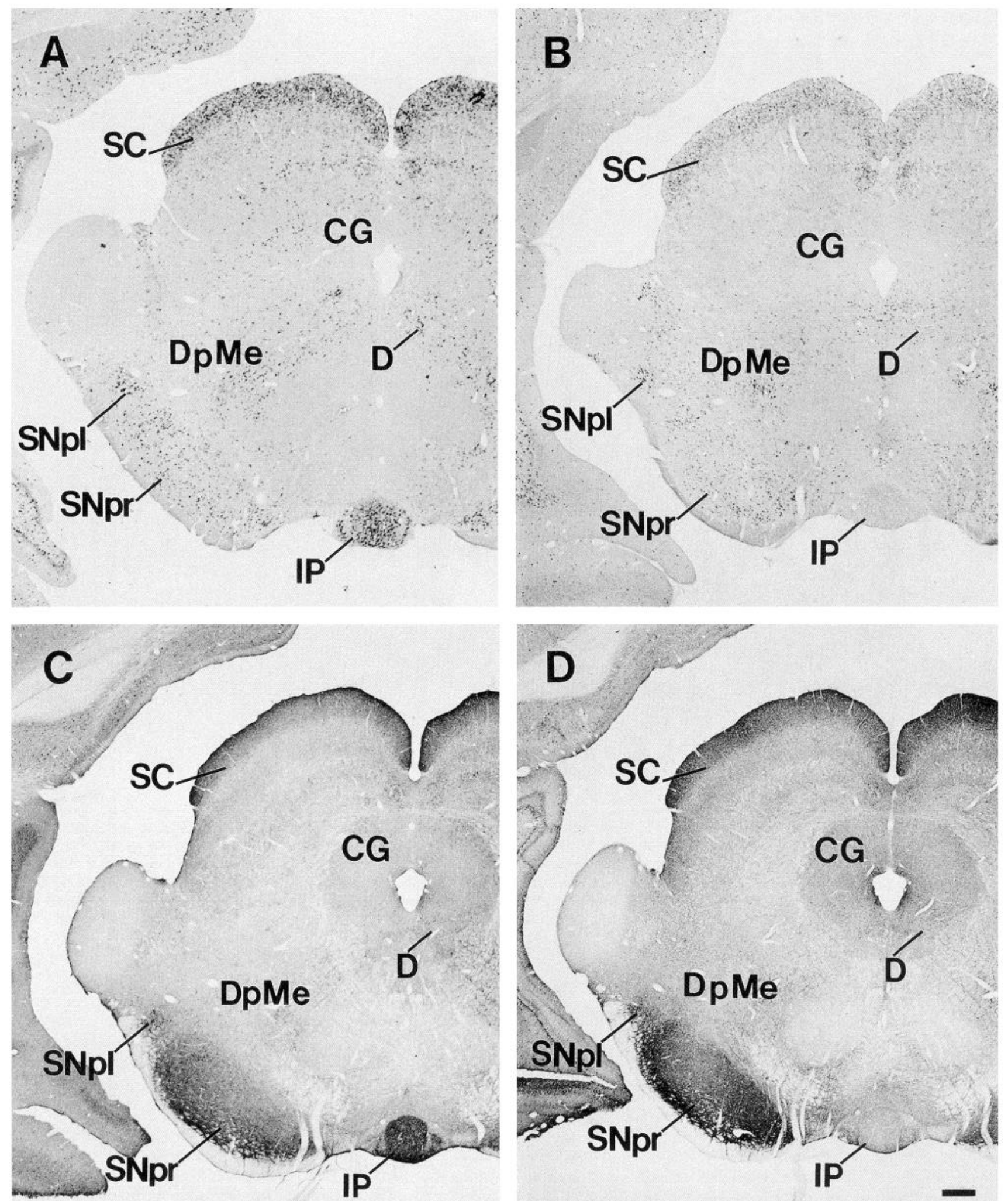

Figure 12. Comparison of labeling for the two GADs and their mRNAs in coronal sections of midbrain. $A$, Numerous GAD67 mRNA-containing neurons are clearly observed in the superior colliculus $(S C)$, substantia nigra pars reticulata $(S N p r)$ and lateralis $(S N p l)$, and in the Darkshevich $(D)$ and interpeduncular $(I P)$ nuclei. Scattered neurons are labeled for GAD67 mRNA in the deep mesencephalic area $(D p M e)$ and central gray $(C G) . B$, Similar groups of neurons are labeled for GAD65 mRNA except for the rostral part of the interpeduncular nucleus $(I P)$, where virtually no labeling is detected. The labeling intensities of most of these GAD65 mRNA-containing neurons are lighter than those observed for GAD67 mRNA-containing neurons (compare $B$ to $A$ ), even after longer times in the color reaction. $C$, With immunohistochemical methods for GAD67, high densities of labeled terminals are evident. This makes detection of labeled cell bodies difficult at low magnification, particularly in the superficial gray layer of the superior colliculus, the substantia nigra pars reticulata, and interpeduncular nucleus. $D$, Similar patterns of terminals labeled for GAD65 are observed in the midbrain except in the rostral part of the interpeduncular nucleus, where virtually no labeled terminals are present. No GAD65-containing cell bodies are detected in most of these regions of the midbrain including the substantia nigra, the deep mesencephalic area and central gray, and the Darkshevich and interpeduncular nuclei. Scale bar, $800 \mu \mathrm{m}$ for $A-D$. 

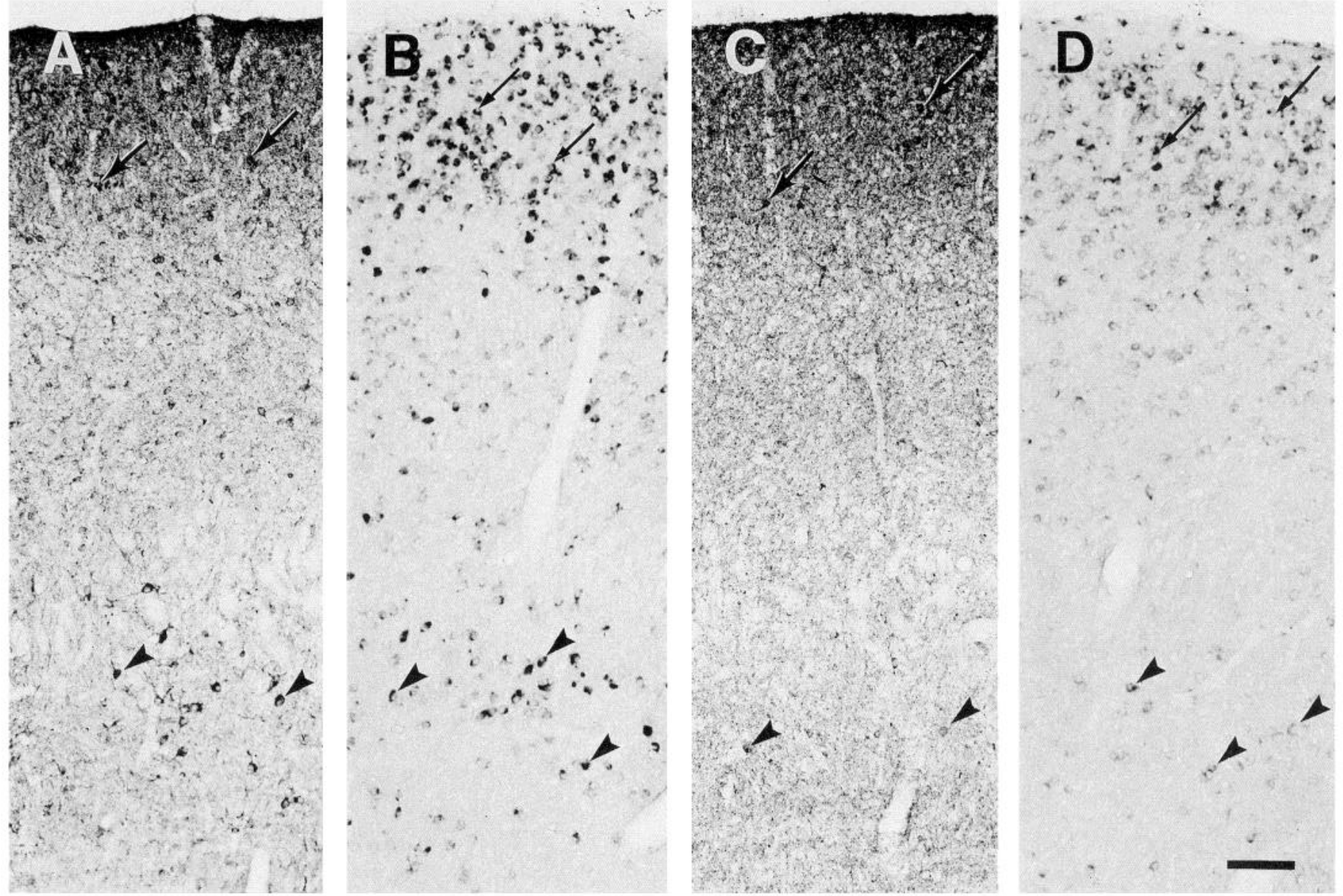

Figure 13. Comparison of cell body labeling for the two GADs and their mRNAs in the superior colliculus. A, Many small cell bodies (arrows) in the superficial gray layer as well as larger neurons (arrowheads) in the deep gray layer are readily labeled for GAD67 and are dispersed among numerous labeled terminals. Small- to medium-size cell bodies with lighter staining are scattered through all layers of the superior colliculus. $B$, Similarly, numerous small neurons (arrows) in the superficial layer as well as large neurons (arrowheads) in the deep gray layer are strongly labeled for GAD67 mRNA. Neurons with a lighter labeling are also present in all layers. C, Cell bodies (arrows) labeled for GAD65 are primarily observed in the superficial gray layer, which also contains a very high density of labeled terminals. Only a few labeled neurons (arrowheads) are present in the deep gray layer, and virtually no cell body labeling is detected in the other layers. $D$, Neurons labeled for GAD65 mRNA are observed in all layers. However, most of the neurons with strong labeling (arrows) are present in the superficial gray layer. The large- to medium-size neurons (arrowheads) in the deep gray layer generally have lighter staining for GAD65 mRNA than for GAD67 mRNA (compare $D$ to $B$ ). Scale bar, 100 $\mu \mathrm{m}$ for $A-D$.

consistently observed in sections processed with GAD65 immunohistochemical methods (Fig. 8B).

The globus pallidus showed similar patterns of cell body labeling with immunohistochemical and in situ hybridization methods for GAD67 and its mRNA but not for GAD65 and its mRNA. Many neurons were heavily labeled for GAD67 mRNA (Fig. $7 A$ ) and clear labeling of cell bodies was observed for GAD67 (Fig. 7B). A similar group of neurons was labeled for GAD65 mRNA, with a lighter intensity of staining than that for GAD67 mRNA, but no cell body labeling for GAD65 was detected (Fig. 8). In both the striatum and globus pallidus, nu- merous terminals were labeled for GAD67 as well as for GAD65 (Figs. $7 B, 8 B$ ).

In many other regions of the CNS, the labeling patterns for immunohistochemistry and in situ hybridization appeared less comparable because of either variations in the intensity of mRNA labeling or the concentration of labeled axon terminals. Several nuclei in the posterior forebrain, including the anterior pretectal nucleus, ventral lateral geniculate nucleus, and caudal part of zona incerta, provided examples of such patterns. In many brain regions, the labeling patterns were similar to those observed in the anterior pretectal nucleus. In this nucleus, a large number

Figure 14. Comparison of labeling for the two GADs and their mRNAs in sagittal sections of inferior colliculus. $A$, Numerous small- to mediumsize neurons (arrows) are strongly labeled for GAD67 mRNA. B, A similar pattern of labeling is evident for GAD65 mRNA-containing neurons (arrows). The intensities of cell body labeling are similar to those observed for GAD67 mRNA (compare $B$ to $A$ ) but after a longer time in the color reaction. $C$, With $\mathrm{K} 2$ antiserum, small to large cell bodies are readily labeled. Many GAD67-labeled terminals are scattered within the neuropil or outline the cell bodies of GAD67-containing neurons (arrowheads). D, With GAD-6 antibody, when Triton is used in the immunohistochemical processing, many more terminals are observed than when no Triton is added or when the sections are processed with K2 antiserum (compare $D$ to $C$ ). However, no cell body labeling is detected in this condition. Scale bars: $A$ and $B, 300 \mu \mathrm{m} ; C$ and $D, 25 \mu \mathrm{m}$. 

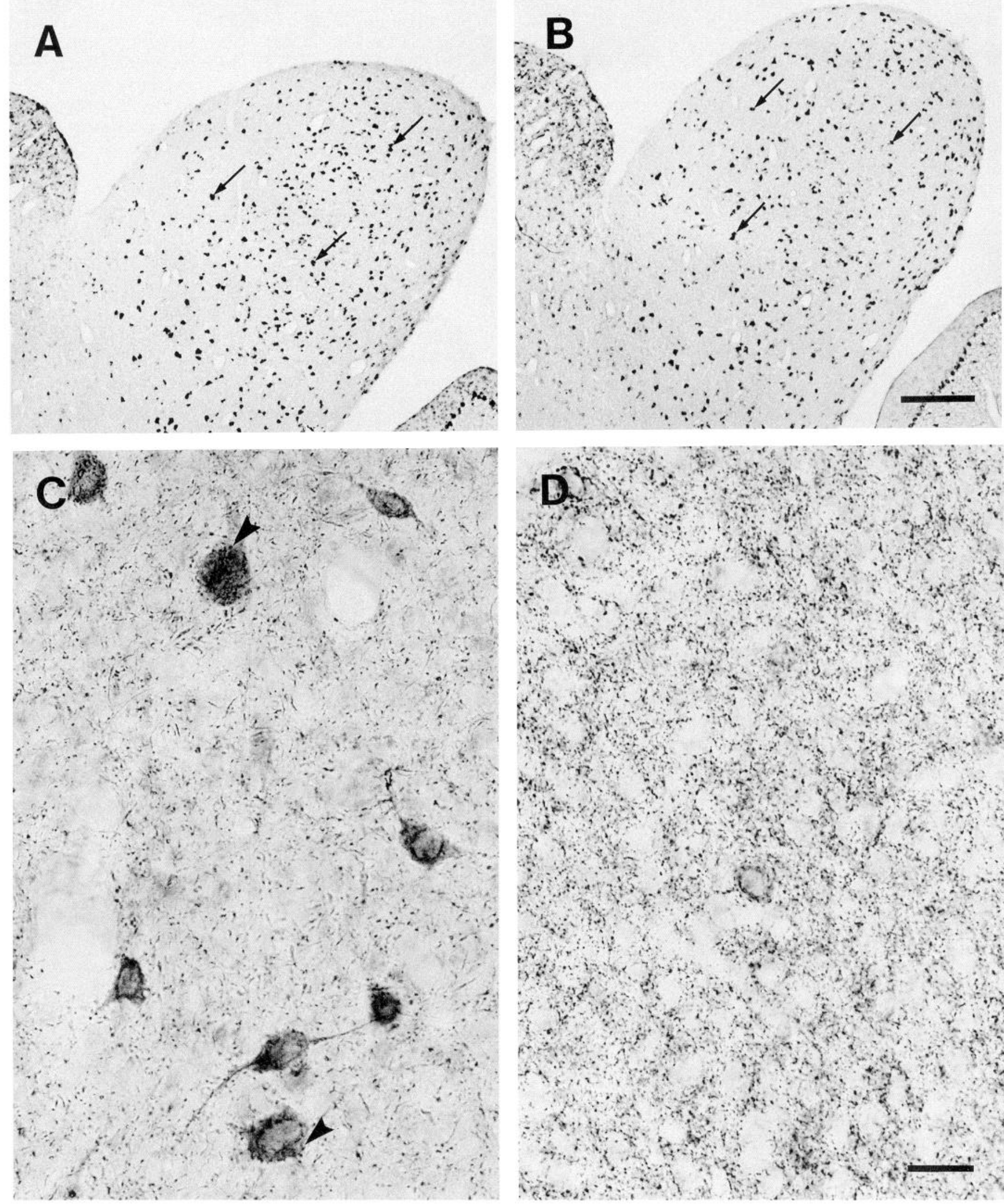

-13.

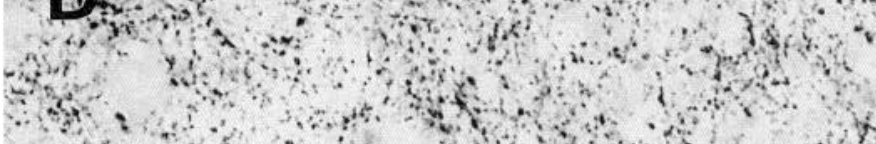

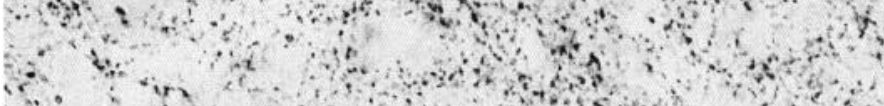

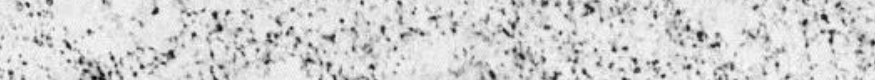

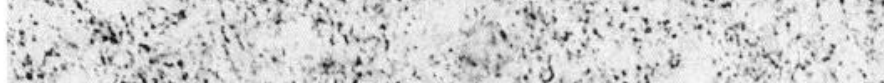

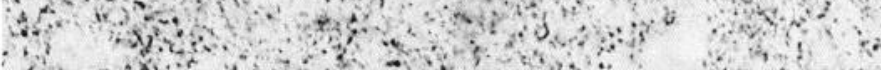
$x^{2}+x^{2}+e^{2}+4$

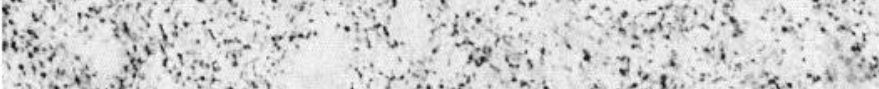
2.

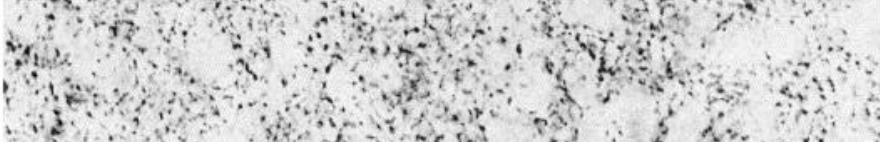

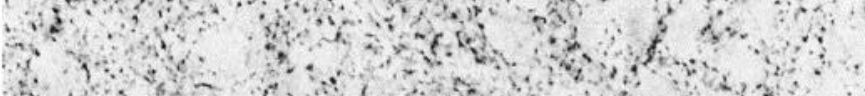

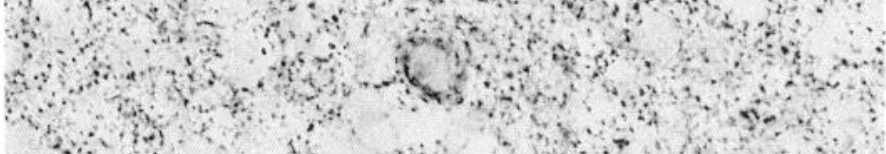

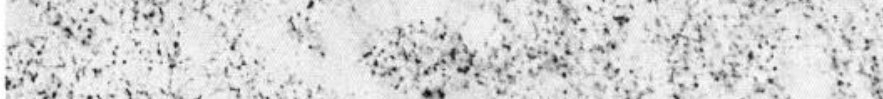

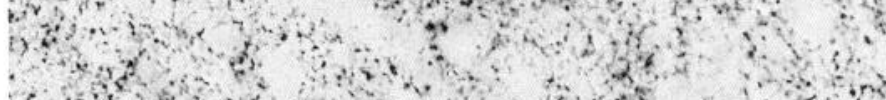

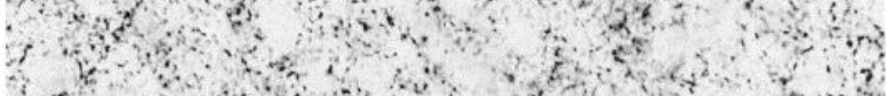

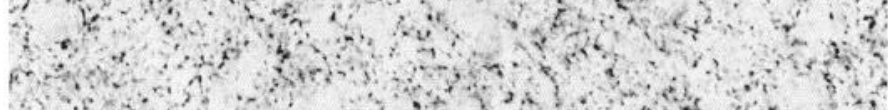

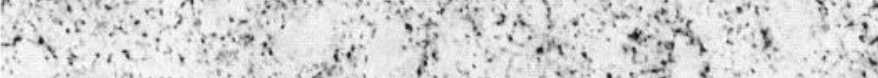

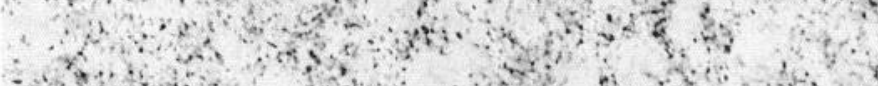

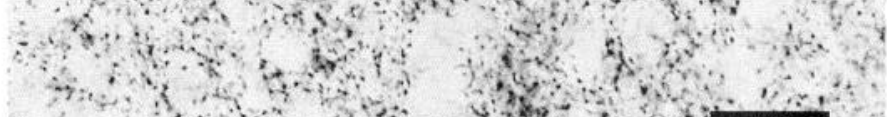

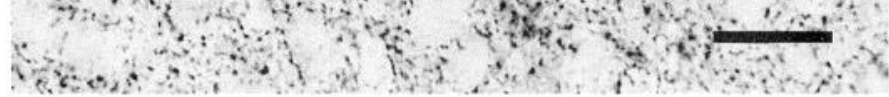


of neurons were heavily labeled for GAD67 mRNA (Fig. 9A), and many cell bodies were also well labeled for GAD67 (Fig. 9C). A similar group of neurons was labeled for GAD65 mRNA (Fig. 9B), but the staining was lighter than that obtained for GAD67 mRNA. Very few cell bodies were labeled for GAD65 with immunohistochemical methods (Fig. 9D). Numerous terminals were labeled for GAD65 and GAD67, but the density was higher in specimens processed for GAD65 (Fig. 9C,D).

In several brain regions, the patterns of labeling were similar to those observed in the ventral lateral geniculate nucleus and adjacent zona incerta and were characterized by strong, distinct labeling of many cell bodies with in situ hybridization methods but virtual occlusion of labeled cell bodies by large numbers of labeled axon terminals in the immunohistochemical preparations. The ventral lateral geniculate nucleus and zona incerta exhibited very large numbers of neurons that were strongly labeled for GAD67 mRNA (Fig. 10A) as wcll as for GAD65 mRNA (Fig. $10 B$ ) with in situ hybridization methods. However, with immunohistochemical methods for GAD67 (Fig. 10C) as well as for GAD65 (Fig. 10D), cell body labeling was very difficult to detect due to the massive terminal fields in the two regions. In these nuclei, the in situ hybridization methods, in contrast to the immunohistochemical methods, allowed a clear visualization of both GAD67- and GAD65-containing cell bodies. In the adjacent dorsal lateral geniculate nucleus, neurons were strongly labeled for both GAD mRNAs (Fig. 10A,B), and in this nucleus, which contained only moderate levels of terminals, labeled cell bodies were also detected in immunohistochemical preparations for both GADs (Fig. 10C,D).

Cell body and terminal labeling. The relationships between cell body labeling (for the GAD mRNAs and their respective proteins) and terminal labeling at sites to which the neurons project were studied in the cerebellum. The relative levels of labeling of the Purkinje cells were compared to the labeling of axon terminals in the deep cerebellar nuclei to which the Purkinje cells project. Purkinje cells were strongly labeled for GAD67 and GAD67 mRNA (Figs. 6A, 11 $A$ ) with immunohistochemistry and in situ hybridization, respectively. In contrast, these neurons were more lightly labeled for GAD65 and its mRNA (Figs. $6 B, 11 B$ ). However, the terminals of these cells, surrounding cell bodies and the proximal dendrites of large unlabeled neurons in the deep cerebellar nuclei, were strongly labeled for GAD65 (Fig. 11D) as well as for GAD67 (Fig. 11C).

\section{Localization of GADs and their mRNAs in the midbrain}

The midbrain illustrated similarities and differences in the localization of the two GADs (Fig. 12C,D) and their mRNAs (Fig. $12 A, B)$ as well as the advantages and disadvantages of the different methods. The present nonradioactive in situ hybridization methods provided a clear visualization of cell bodies labeled for each GAD mRNA (Fig. 12A,B). In the midbrain, all known classes of GABA neurons were readily labeled for GAD67 mRNA, and these included selected neurons in the superior colliculus, a vast majority of neurons in the substantia nigra, pars reticularis and lateralis, scattered neurons in the deep mesencephalic area and central gray, and numcrous neurons in the interpeduncular nucleus (Fig. 12A). The distribution of GAD65 mRNA-containing neurons was very similar to that of GAD67 mRNA-containing neurons in most regions of the midbrain, including the superior colliculus, substantia nigra pars reticulata and lateralis, and the deep mesencephalic area and central gray (Fig. 12B). However, some differences were found. Some mid- brain neurons appeared to express only one form of GAD mRNA. In the rostral part of the interpeduncular nucleus, virtually no labeling was detected for GAD65 mRNA (Fig. 12B), while strong labeling for GAD67 mRNA-containing cell bodies was present in this nucleus. In addition, longer color reaction times were required for optimal staining of many GAD65 mRNA-containing neurons than for such staining of GAD67 mRNA-containing neurons, and this suggested higher levels of mRNA for GAD67 than for GAD65 in the midbrain.

Visualization of the cell bodies of many of these GABA neurons was difficult with immunohistochemical methods for both GAD65 and GAD67 due to the high levels of terminal staining within the midbrain (Fig. 12C,D). Very high densities of labeled terminals were observed in the superficial gray layer of the superior colliculus and in substantia nigra, pars reticulata, for both GADs, although GAD65-labeled terminal fields were particularly cxtcnsive (Fig. 12C,D). In addition, a high density of GAD67-labeled terminals was evident in the rostral part of the interpeduncular nucleus (Fig. 12C), but virtually no GAD65containing terminals were detected in this region (Fig. 12D). When studied at high magnification, numerous neurons in the superior colliculus, substantia nigra pars reticularis and lateralis, and interpeduncular nucleus were labeled for GAD67. However, no GAD65-labeled cell bodies were detected in several of these brain regions including the substantia nigra, deep mesencephalic area and central gray, and the rostral part of the interpeduncular nucleus.

The superior colliculus is a laminar structure in which the patterns of labeling for the two GADs and their mRNAs varied according to the layers. Labeling in the superior colliculus showed that when cell bodies were strongly labeled for each GAD mRNA with in situ hybridization methods (Fig. 13B,D), similar patterns of cell body labeling were observed for both GADs with immunohistochemical methods (Fig. 13A,C). For example, small cell bodies in the superficial gray layer were labeled in all preparations, although at low magnification these neurons were difficult to visualize because of the high concentration of labeled terminals in this region. In contrast, when the labeling for the GAD mRNA was not strong, there was often either light or no immunolabeling of the cell bodies. For example, the mediumsize neurons in the deep gray layers exhibited strong GAD67 mRNA labeling (Fig. 13B) but a much lighter staining for GAD65 mRNA (Fig. 13D). These neurons were labeled for GAD67 (Fig. $13 \mathrm{~A}$ ), but very few cell bodies were labeled for GAD65 with immunohistochemical methods (Fig. 13C).

In the inferior colliculus, in situ hybridization provided a clear visualization of a large population of neurons labeled for each GAD mRNA (Fig. 14A,B). Numerous neurons throughout the inferior colliculus were strongly labeled for GAD67 mRNA. The same populations of neurons were moderately to strongly labeled for GAD65 mRNA, although longer color reaction times than for GAD67 mRNA were required to achieve this level of labeling. Immunohistochemical methods using GAD67 antiserum readily labeled many neurons in the inferior colliculus and, in addition, allowed visualization of GAD67-containing terminals scattered within the neuropil as well as surrounding many of the labeled cell bodies (Fig. 14C). Even though only a few cell bodies in the inferior colliculus were labeled for GAD65, the immunohistochemical methods using GAD-6 antibody demonstrated numerous GAD65-containing terminals. The number of labeled terminals was further increased when Triton was included in the immunohistochemical processing (Fig. 14D). 


\section{Discussion}

\section{Intraneuronal distribution of GAD proteins}

A major goal of the present study was to determine if the two GAD proteins have different intracellular distributions in many regions of the CNS and thus determine the generality of previous findings in the cerebellar cortex (Kaufman et al., 1991), The immunohistochemical findings indicate that both GAD proteins are present in neuronal cell bodies as well as axon terminals, but there are definite differences in the staining patterns for the two proteins. With the current immunohistochemical methods, many GAD-containing cell bodies were labeled more readily with the $\mathrm{K} 2$ antiserum that primarily recognizes GAD67 than with the GAD-6 monoclonal antibody to GAD65. In contrast, GAD-containing terminals were labeled more prominently with the monoclonal antibody that recognizes GAD65 than with the antiserum to GAD67. Our interpretation of these findings is that GAD67 is more highly concentrated than GAD65 in many GAD-containing cell bodies whereas GAD65 is more highly concentrated than GAD67 in many axon terminals. This suggestion is based primarily on the different patterns of labeling and not on different intensities of staining obtained with the two antisera. Since differences in staining intensities can be due to the use of different antisera, they cannot be used to compare directly the amounts of GAD65 and GAD67. Thus subsequent discussions of possible differences in the concentrations of the two GAD proteins are based on preferential labeling of certain neuronal elements with each of the currently available reagents.

Other explanations for the different labeling patterns include the possibility that the two GAD proteins might be similarly distributed in the neurons but that their antigenic sites might differ in their accessibility to the different antibodies. However, biochemical evidence that GAD65 is more highly concentrated than GAD67 in synaptosomal preparations from whole brain (Erlander et al., 1991) is consistent with the observed differences in the immunohistochemical localization of the two proteins. Likewise, in extracts of the intermediate lobe of the pituitary, where GAD is present exclusively in nerve terminals, the ratio of the lower to higher molecular weight form of GAD is substantially larger than that in whole brain extracts (Henry and Tappaz, 1991).

In addition, several immunohistochemical findings are consistent with the suggestion that differences in cell body staining for GAD67 and GAD65 reflect differences in the concentrations of the two proteins. Differences in the intensities of cell body labeling among populations of GAD-containing neurons were observed in the same sections for each GAD. For example, although many GABA cell bodies were either lightly labeled or unlabeled for GAD65, some populations of neurons like those in the reticular nucleus, the periglomerular cells in the olfactory bulb, and the Golgi cells in the cerebellar cortex showed distinct labeling, similar to that for GAD67. The fact that these neurons were clearly labeled for GAD65 suggests that the absence or low levels of cell body labeling for GAD65 in most brain regions, when compared to that for GAD67, cannot be explained solely by different accessibility of the antigens to the antibodies and probably reflects different concentrations of the two GADs.

The strong labeling of many cell bodies with antiserum to GAD67 is particularly interesting because several previous antisera to GAD have produced very little labeling of the cell bodies (Ribak et al., 1978; Oertel et al., 1981 b; Perez de la Mora et al., 1981) unless either the animals were pretreated with col- chicine to limit axonal transport (Ribak et al., 1978) or special fixatives were used to enhance cell body labeling (Mugnaini and Oertel, 1985). The limited cell body labeling obtained with previous antisera has generally been assumed to be due to low levels of GAD within the cell bodies. However, such patterns of labeling also may reflect the fact that these antisera are primarily recognizing GAD65, which is most abundant in the terminals and would have been enriched in the synaptosomal or crude mitochondrial fractions from which the GAD was purified $(\mathrm{Wu}$ et al., 1973; Saito et al., 1974; Oertel et al., 1981a; Perez de la Mora et al., 1981). In contrast to previously used antigens, the GAD used to obtain the K2 antiserum was produced in an $E$. coli bacterial expression system by using GAD67 cDNA to direct GAD67 synthesis (Kaufman et al., 1991). Thus the uniquencss of the GAD antigen is presumably responsible for the selectivity of the antiserum primarily for GAD67 and the related enhancement of cell body labeling with the immunohistochemical methods. This suggestion is supported by the findings that another GAD antiserum obtained from rabbits immunized with bacterially produced GAD of the higher molecular weight (Katarova et al., 1990) also recognizes predominantly GAD67 and labels cell bodies as well as axon terminals with appropriate immunohistochemical methods. Relatively low amounts of GAD67 in previous antigen preparations may account for the lack of strong cell body labeling with several other GAD antisera.

The ability of the $\mathrm{K} 2$ antiserum to label GAD-containing neuronal cell bodies has been emphasized because this is one of the distinct characteristics of this GAD antiserum. However, numerous axon terminals are also labeled with this antiserum (Gonzales et al., 1991; Kaufman et al., 1991; present findings), and these observations are consistent with biochemical findings that synaptosomes contain both molecular weight forms of GAD (Erlander et al., 1991; Martin et al., 1991b).

In contrast to the labeling obtained with the $\mathrm{K} 2$ antiserum to GAD67, the monoclonal antibody that specifically recognizes GAD65 (GAD-6; Chang and Gottlieb, 1988) labeled axon terminals most prominently, although it also labeled some neuronal cell bodies. While large numbers of terminals were labeled even without the use of detergents in the immunohistochemical procedures, the number and apparent size of the terminals were substantially increased by pretreating the fixed tissue with a detergent such as Triton X-100. Inclusion of detergent in the immunohistochemical procedures also increased the terminal labeling with the $\mathrm{K} 2$ antisera that recognizes GAD67, as has been described by Gonzales et al. (1991). However, the resultant terminal fields were never as extensive as those observed with GAD65 labeling under the same conditions. Such differences, as illustrated for the cerebellar cortex, were observed to varying extents in all brain regions examined in the present studies.

These immunohistochemical findings further support the suggestion that GAD65 is the most prominent form of GAD in the axon terminals. It has been demonstrated previously that the majority of apoGAD (GAD without its bound cofactor) is GAD65 (Kaufman et al., 1991; Martin et al., 1991a,b), and axon terminals would appear to be a functionally appropriate location for this form of GAD. At these sites, conversion of the apoenzyme to the holoenzyme or active form of GAD could be regulated readily by the local environment, and immediate influences on the synthesis of GABA for synaptic activity could be exerted (Kaufman et al., 1991; Martin, 1993).

The factors that are responsible for apparent differences in 
the relative amounts of the two GAD proteins in axon terminals are not known. The stronger labeling of the terminals for GAD65 could reflect differences in the relative amounts of GAD65 and GAD67 that are transported to the axon terminals, with larger amounts of GAD65 being transported from the cell bodies. Alternatively, GAD67 might be degraded more rapidly than GAD65 within the axon terminals, and thus, the labeling for GAD67 in the terminals would be less.

Different intraterminal compartmentation of the two GAD forms might also contribute to differences in terminal labeling. Although GAD is generally considered to be a cytoplasmic enzyme, several studies have noted that, under certain conditions, some GAD is associated with membranes (Salganicoff and De Robertis, 1965; Fonnum, 1968; Martin and Rimvall, 1993). Chang and Gottlieb (1988) found substantial amounts of GAD in membrane-enriched fractions, and a large percentage of the membrane-associated GAD was solubilized by Triton X-100. The membrane-associated GAD included lower- and highermolecular-weight proteins that appear to correspond to GAD65 and GAD67. Interestingly, in an earlier biochemical study of the properties of GAD binding to liposomes, Covarrubias and Tapia (1980) found that the GAD which bound to the liposomes was deficient in free pyridoxal 5 -phosphate as compared with that which remained soluble. Martin et al. (1991b) have recently established that the majority of apoGAD in the CNS is GAD65. Together these findings suggest that much of the membraneassociated GAD corresponds to apoGAD65. This idea is supported by recent findings that much GAD65 is firmly anchored to membranes in pancreatic $\beta$-cells (Christgau et al., 1991, 1992) and that GAD65, but not GAD67, may have an intrinsic capacity to associate with some membranes due to a targeting signal in the $\mathrm{N}$-terminal region of the protein that directs it to Golgi complex-associated structures (Solimcna ct al., 1993).

However, recent findings indicate that GAD65 is not exclusively associated with membranes but exists in multiple forms that include both membrane-bound and soluble forms, and these forms apparently result from posttranslational modifications (Christgau et al., 1991, 1992). If GAD-6 were to recognize only one of these forms of GAD65, this could account for the differential labeling between cell bodies and terminals obtained with the antibody, but this does not appear to be the case since GAD-6 recognizes both membrane-bound and soluble forms of GAD65 on Western blots (Christgau et al., 1991). While the GAD-6 antibody does not distinguish between these particular forms of GAD65, additional GAD forms may be identified that will be recognized selectively by such GAD antibodies, and our view of the localization of the different GAD forms can be further refined.

Since some GAD65 appears to be membrane-bound, the substantial increase in labeling of axon terminals for GAD65 after treatment of the tissue sections with detergent might be interpreted as an effect of detergent on the association of this GAD protein with membranes. The greater enhancement of labeling for GAD65 than for GAD67 is consistent with different compartmentation of the two GAD proteins within the terminals; GAD67 might be located primarily within the cytoplasm whereas GAD65 might be associated with synaptic vesicle or plasma membranes. In these latter locations, membrane permeabilization might be required to reveal antigenic sites. However, it is also possible that the detergent simply increases the accessibility of the reagents used for localization of both GAD proteins to the interior of the axon terminals. In this case, the greater enhancement of terminal labeling for GAD65 than for GAD67 might reflect the different amounts of each G $\Lambda D$ isoform within the cytoplasm of the terminals rather than different intraterminal locations of the two proteins.

\section{Comparative localization of $G A D$ proteins and $m R N A s$}

A second goal of this study was to compare the localization and levels of labeling of the two GAD proteins and their respective mRNAs in order to identify relationships that could reflect posttranscriptional events and functional differences between the two GAD isoforms. The results demonstrated a strong parallel between the intensity of immunohistochemical labeling of the cell bodies and the levels of mRNA labeling for both forms of GAD. Many groups of GAD-containing cell bodies were distinctly labeled with immunohistochemical methods for GAD67, and these same groups of neurons were heavily labeled for GAD67 mRNA. Examples of such neurons included the Purkinje cells in the cerebellar cortex, nonpyramidal cells in the cerebral cortex, and neurons of the reticular nucleus of the thalamus. Similarly, neurons with weak immunohistochemical labeling for GAD67, such as the vast majority of striatal neurons, were lightly labeled for GAD67 mRNA. Similar labeling for GAD67 mRNA has been observed in several previous in situ hybridization studies (Wuenschell et al., 1986; Chesselet et al., 1987; Julien et al., 1987; Benson et al., 1989; Lindcfors ct al., 1989; Ferraguti et al., 1990; Okamura et al., 1990; Benson et al., 1991, 1992; Retaux et al., 1992; Feldblum et al., 1993). These studies also noted a generally good correspondence between the distribution of neurons that were heavily labeled for GAD67 mRNA and groups of known GABA neurons such as those identified by earlier immunohistochemical studies with antisera that recognize both molecular sizes of GAD or GABA. However, less correspondence was noted between the in situ hybridization results and previous immunohistochemical descriptions of GABA neurons that, in the present study, were relatively lightly labeled for GAD67 mRNA.

Cell bodies that were readily labeled with immunohistochemical methods for GAD65 were also strongly labeled for GAD65 mRNA, and these patterns of labeling were observed in neurons in the reticular nucleus of the thalamus and periglomerular cells in the olfactory bulb. However, many cell bodies were not readily labeled by the immunohistochemical localization of GAD65. Such neurons included some nonpyramidal cells of the cerebral cortex, Purkinje and stellate cells in the cerebellar cortex, and many neurons in the anterior pretectal nucleus. While these groups of neurons were labeled for GAD65 mRNA, the levels of labeling were often considerably lower than those for GAD67 $\mathrm{mRNA}$, and longer times in the color reaction were necessary to obtain the labeling (Esclapez et al., 1993).

Thus, for both forms of GAD, high levels of GAD mRNA labeling were generally accompanied by readily detectable levels of immunohistochemical labeling of the related protein in the cell bodies. Groups of neurons that showed low levels of labeling for either GAD mRNA generally exhibited low levels or an absence of cell body labeling for the respective protein with immunohistochemical methods.

The absence of cell body labeling for GAD65 when these neurons were labeled for GAD65 mRNA could be interpreted as a lack of translation. However, this appears unlikely because we did not observe examples of neurons with a high concen- 
tration of mRNA and no cell body labeling for the protein; high levels of mRNA were consistently associated with detection of the protein in the cell bodies. In addition, even when no cell body labeling for the protein was evident, terminal staining was present in the region to which the neurons are known to project, suggesting the presence of the protein in a different part of the neuron rather than a lack of synthesis of the protein. These results suggest that neurons that express either GAD mRNA also express the corresponding protein.

In contrast to these parallels between the levels of labeling of cell bodies with immunohistochemical and in situ hybridization methods, the levels of cell body labeling for the GAD mRNAs were not closely related to the levels of axon terminal labeling of the respective groups of neurons. For example, despite relatively low levels of GAD65 mRNA in Purkinje cells, as compared to the levels of GAD67 mRNA, the axon terminals of these neurons in the deep cerebellar nuclei and the lateral vestibular nucleus were strongly labeled for the GAD65 protein. In many other brain regions, such as the cerebral cortex and superior colliculus, the levels of cell body labeling for GAD65 mRNA were also relatively low as compared to those for GAD67 mRNA (Esclapez et al., 1993). However, in the same regions, numerous axon terminals were strongly labeled for GAD65. Since many of the GAD-containing terminals in these regions are derived from intrinsic neurons, the findings provide additional examples of the lack of close correspondence between the levels of GAD65 mRNA labeling and the levels of axon terminal labeling obtained with the current immunohistochemical methods. Gonzales et al. (1991) also noted substantial GAD67-containing terminal fields, labeled with the K2 antiserum, in the globus pallidus and substantia nigra, pars reticulata, even though they observed relatively low levels of GAD67 mRNA in the vast majority of projection neurons of the striatum. Thus, for both GAD mRNAs, labeling is consistently observed in the cell bodies of neurons that contribute to specific fields of GADcontaining terminals. However, strong labeling in particular terminal fields is not always accompanied by similarly strong levels of cell body labeling for the related GAD mRNA in the neurons of origin.

Low levels of GAD65 protein in the cell bodies, as suggested by immunocytochemical findings, might be a reflection of either low rates of synthesis or rapid transport of GAD65 from the cell bodies to the terminals. The accompanying relatively low levels of GAD65 mRNA, as compared to the levels of GAD67 mRNA, suggest that, under normal conditions, the synthesis of GAD65 is rather low in many neurons. However, the strong labeling of GAD65 in axon terminals suggests that this protein accumulates in the axon terminals where it may constitute a major pool of GAD at synaptic sites.

The apparently different levels of GAD67 and GAD65 and their respective mRNAs in many neuronal cell bodies may be related to different functions and associated rates of synthesis of the two proteins. The presence of high levels of both GAD67 protein and mRNA in cell bodies would be consistent with relatively high rates of synthesis of this protein. It has been suggested that this GAD form might be prominent in neurons with tonic firing patterns or that it might be associated primarily with a metabolic pool of GABA (for reviews, see Erlander and Tobin, 1991; Esclapez et al., 1993; Feldblum et al., 1993; Martin and Rimvall, 1993). Such functions might require a relatively constant level of GAD synthesis; GAD67 mRNA might be maintained at relatively high levels; and the newly synthesized protein might then be evident in the cell bodies prior to being transported to the axon terminals.

The supply of GAD65 within the axon terminals may be sufficient to meet many of the local needs for synaptic GAD through the conversion of the apo- to the holoenzyme or active form of GAD. Under normal conditions, only low levels of GAD65 synthesis might be required, and the levels of GAD65 in the cell bodies would remain relatively low. However, if increased demands for GABA synthesis were maintained over long periods of time, one would anticipate that the levels of GAD65 mRNA and protein would increase.

These ideas are consistent with the general hypothesis that GAD65 and GAD67 are regulated differently, with greater dependence of GAD67 than GAD65 on regulation at the mRNA level (for review, see Martin and Rimvall, 1993). Indeed, several studies have demonstrated rapid changes in GAD67 mRNA levels in response to various lesions and pharmacological manipulations (Vernier et al., 1988; Lindefors et al., 1989; Feldblum et al., 1990; Litwak et al., 1990; Segovia et al., 1990, 1991; O'Connor et al., 1991; Caboche et al., 1992; Kincaid et al., 1992; Mercugliano et al., 1992a; Soghomonian et al., 1992; Salin and Chesselet, 1993). In contrast, in the few studies that have examined GAD65 mRNA levels, either no change or only slight alterations have been detected (Soghomonian and Chesselet, 1992).

\section{Complementary morphological descriptions}

The differential localization of the two proteins and their mRNAs provide complementary morphological information about neurons that synthesize GAD and presumably GABA. The antiserum to GAD67 allows consistent labeling of many GAD-containing cell bodies without the necessity of colchicine pretreatment. However, since the GAD67 antiserum also labels axon terminals, GAD-containing cell bodies remain difficult to visualize in some brain regions because of their occlusion by terminals. In these instances, in situ hybridization methods prove particularly useful for identifying GAD mRNA-containing cell bodies since labeling is confined to cell bodies and, in some brain regions, the in situ hybridization methods may provide a more complete and reliable indication of the numbers of GADsynthesizing cell bodies than immunohistochemical methods. This is particularly true for GAD65-containing neurons since the number of these neurons would be severely underestimated with immunohistochemical methods and the present antibody to GAD65. However, the immunohistochemical localization of GAD65 provides a more complete view of the relative numbers and morphological characteristics of GAD-containing terminals than the localization of GAD67. When the numbers of GAD65labeled terminals are maximized by the use of a detergent in the immunohistochemical procedures, the abundance in many brain regions is quite striking. Finally, in addition to being useful for labeling neuronal cell bodies, the antiserum to GAD67 can provide unique information about the relationship between GAD67-containing cell bodies and terminals since both cell bodies and some terminals are labeled by the antiserum. 'Thus the present findings suggest that no single method provides a comprehensive view of GAD-synthesizing neurons, but each method has its distinct advantages and can be selected to answer specific questions. 


\section{References}

Benson DL, Isackson PJ, Hendry SHC, Jones EG (1989) Expression of glutamic acid decarboxylase m.RNA in normal and monocularly deprived cat visual cortex. Mol Brain Res 5:279-287.

Benson DL, Isackson PJ, Hendry SHC, Jones EG (1991) Differential gene expression for glutamic acid decarboxylase and type II calciumcalmodulin-dependent protein kinase in basal ganglia, thalamus, and hypothalamus of the monkey. J Neurosci 11:1540-1564.

Benson DL, Isackson PJ, Gall CM, Jones EG (1992) Contrasting patterns in the localization of glutamic acid decarboxylase and $\mathrm{Ca}^{2+}$ calmodulin protein kinase gene expression in the rat central nervous system. Neuroscience 46:825-849.

Bu D-F, Erlander MG, Hitz BC, Tillakaratne NJK, Kaufman DL, Wagner-McPherson CB, Evans GA, Tobin AJ (1992) Two human glutamate decarboxylases, 65-kDa GAD and 67-kDa GAD, are each encoded by a single gene. Proc Natl Acad Sci USA 89:2115-2119.

Caboche J, Vernier P, Rogard M, Julien J-F, Mallet I, Besson M-I (1992) Role of dopaminergic $D_{2}$ receptors in the regulation of glutamic acid decarboxylase messenger RNA in the striatum of the rat. Eur J Neurosci 4:438-447.

Chang Y-C, Gottlieb DI (1988) Characterization of the proteins purified with monoclonal antibodies to glutamic acid decarboxylase. $J$ Neurosci 8:2123-2130.

Chesselet M-F, Weiss L, Wuenschell C, Tobin AJ, Affolter H-U (1987) Comparative distribution of mRNAs for glutamic acid decarboxylase, tyrosine hydroxylase, and tachykinins in the basal ganglia: an in situ hybridization study in the rodent brain. J Comp Neurol 262:125140.

Christgau S, Schierbeck H, Aanstoot H-J, Aagaard L, Begley K, Kofod H, Hejnaes K, Baekkeskov S (1991) Pancreatic $\beta$ cells express two autoantigenic forms of glutamic acid decarboxylase, a 65-kDa hydrophilic form and a 64-kDa amphiphilic form which can be both membrane-bound and soluble. J Biol Chem 266:21257-21264.

Christgau S, Aanstoot H-J, Schierbeck H, Begley K, Tullin S, Hejnaes $K$, Baekkeskov S (1992) Membrane anchoring of the autoantigen $\mathrm{GAD}_{65}$ to microvesicles in pancreatic $\beta$-cells by palmitoylation in the $\mathrm{NH}_{2}$-tcrminal domain. J Cell Biol 118:309-320.

Covarrubias M, Tapia R (1980) Brain glutamate decarboxylase: properties of its calcium-dependent binding to liposomes and kinetics of the bound and the free enzyme. J Neurochem 34:1682-1688.

Erlander MG, Tobin AJ (1991) The structural and functional heterogeneity of glutamic acid decarboxylase: a review. Neurochem Res 16: 215-226.

Erlander MG, Tillakaratne NJK, Feldblum S, Patel N, Tobin AJ (1991) Two genes encode distinct glutamate decarboxylases. Neuron 7:91100.

Esclapez M, Tillakaratne NJK, Tobin AJ, Houser CR (1991) Detection of two forms of GAD and their InRNAs in ral brain by immunohistochemistry and non-radioactive in situ hybridization. Soc Neurosci Abstr 17:416.

Esclapez M, Tillakaratne NJK, Tobin AJ, Houser CR (1993) Comparative localization of mRNAs encoding two forms of glutamic acid decarboxylase with nonradioactive in situ hybridization methods. J Comp Neurol 331:339-362.

Feldblum S, Ackermann RF, Tobin AJ (1990) Long-term increase of glutamate decarboxylase mRNA in a rat model of temporal lobe epilepsy. Neuron 5:361-371.

Feldblum S, Erlander MG, Tobin AJ (1993) The different distributions of GAD65 and GAD67 mRNAs suggest that the two glutamate decarboxylases play distinctive functional roles. J Neurosci Res 34:689706.

Ferraguti F, Zoli M, Aronsson M, Agnati LF, Goldstein M, Filer D, Fuxe K (1990) Distribution of glutamic acid decarboxylase messenger RNA-containing nerve cell populations of the male rat brain. J Chem Neuroanat 3:377-396.

Fonnum F (1968) The distribution of glutamate decarboxylase and aspartatetransaminase in subcellular fractions of rat and guinca-pig brain. Biochem J 106:401-417.

Gonzales C, Kaufman DL, Tobin AJ, Chesselet M-F (1991) Distribution of glutamic acid decarboxylase $\left(M_{r} 67000\right)$ in the basal ganglia of the rat: an immunohistochemical study with a selective cDNAgenerated polyclonal antibody. J Neurocytol 20:953-961.

Hemmati-Brivanlou A, Frank D, Bolce ME, Brown BD, Sive HL, Harland RM (1990) Localization of specific mRNAs in Xenopus em- bryos by whole-mount in situ hybridization. Development 110:325330.

Henry S, Tappaz M (1991) Relative enrichment of the lighter $59 \mathrm{kDa}$ form of glutamic acid decarboxylase in nerve endings: an immunoblotting study in pituitary neurointermediate lobe. Neurosci Lett 131: 253-256.

Houser CR, Miyashiro JE, Kaufman DL, Tobin AJ (1989) Immunocytochemical studies using a new antiserum against bacterially produced feline glutamate decarboxylase. Soc Neurosci Abstr 15:488.

Julien J-F, Legay F, Dumas S, Tappaz M, Mallet J (1987) Molecular cloning, expression and in situ hybridization of rat brain glutamic acid decarboxylase messenger RNA. Neurosci Lett 73:173-180.

Julien J-F, Samama P, Mallet J (1990) Rat brain glutamic acid decarboxylase sequence deduced from a cloned cDNA. J Neurochem 54:703-705.

Katarova Z, Szabo G, Mugnaini E, Greenspan RJ (1990) Molecular identification of the $62 \mathrm{kd}$ form of glutamic acid decarboxylase from the mouse. Eur J Neurosci 2:190-202.

Kaufman DL, McGinnis JF, Krieger NR, Tobin AJ (1986) Brain glutamate decarboxylase cloned in $\lambda \mathrm{gt}-11$ : fusion protein produces $\gamma$-aminobutyric acid. Science 232:1138-1140.

Kaufman DL, Houser CR, Tobin AJ (1991) Two forms of the gammaaminobutyric acid synthetic enzyme glutamate decarboxylase have distinct intraneuronal distributions and cofactor interactions. J Neurochem 56:720-723.

Kincaid AF, Albin RL, Newman SW, Penney JB, Young AB (1992) 6-Hydroxydopamine lesions of the nigrostriatal pathway alter the expression of glutamate decarboxylase messenger RNA in rat globus pallidus projection neurons. Neuroscience 51:705-718.

Kobayashi Y, Kaufman DL, Tobin AJ (1987) Glutamic acid decarboxylase cDNA: nucleotide sequence encoding an enzymatically aclive fusion protein. J Neurosci 7:2768-2772.

Lindefors N, Brene S, Herrera-Marschitz M, Persson H (1989) Region specific regulation of glutamic acid decarboxylase mRNA expression by dopamine neurons in rat brain. Exp Brain Res 77:611-620.

Litwak J, Mercugliano M, Chesselet M-F, Oltmans GA (1990) Increased glutamic acid decarboxylase (GAD) mRNA and GAD activity in cerebellar Purkinje cells following lesion-induced increases in cell firing. Neurosci Lett 116:179-183.

Lu W, Haber SN (1992) In situ hybridization histochemistry: a new method for processing material stored for several years. Brain Res 578:155-160.

Martin DL (1993) Short-term control of GABA synthesis in brain. Prog Biophys Mol Biol 60:17-28.

Martin DL, Rimvall K (1993) Regulation of gamma-aminobutyric acid synthesis in the brain. J Neurochem 60:395-407.

Martin DL, Martin SB, Wu SJ, Espina N (1991a) Cofactor interactions and the regulation of glutamate decarboxylase activity. Neurochem Res 16:243-249.

Martin DL, Martin SB, Wu SJ, Espina N (1991b) Regulatory properties of brain glutamate decarboxylase (GAD): the apoenzyme of GAD is present principally as the smaller of two molecular forms of GAD in brain. J Neurosci 11:2725-2731.

Mercugliano M, Saller CF, Salama AI, I J'Prichard DC, Chesselet M-F (1992a) Clozapine and haloperidol have differential effects on glutamic acid decarboxylase mRNA in the pallidal nuclei of the rat. Neuropsychopharmacology 6:179-187.

Mercugliano M, Soghomonian J-J, Qin Y, Nguyen HQ, Feldblum S, Erlander MG, Tobin AJ, Chesselet M-F (1992b) Comparative distribution of messenger RNAs encoding glutamic acid decarboxylases $\left(M_{r} 65,000\right.$ and $\left.M, 67,000\right)$ in the basal ganglia of the rat. J Comp Neurol 318:245-254.

Mugnaini E, Oertel WH (1985) An atlas of the distribution of GABAergic neurons and terminals in the rat CNS as revealed by GAD immunohistochemistry. In: Handbook of chemical neuroanatomy, Vol 4, GABA and neuropeptides in the CNS, Pt I (Bjorklund A, Hokfelt T, eds), pp 436-608. Amsterdam: Elsevier.

O'Connor WP, Lindefors N, Brené S, Herra-Marschitz M, Persson H, Ungerstedt U (1991) Short-term dopaminergic regulation of GABA release in dopamine deafferented caudate-putamen is not directly associated with glutamic acid decarboxylase gene expression. Neurosci Lett 128:66-70.

Oertel WH, Schmechel DE, Tappaz ML, Kopin IJ (1981a) Production of a specific antiserum to rat brain glutamic acid decarboxylase by injection of an antigen-antibody complex. Neuroscience 6:2689-2700. 
Ocrtel WH, Schmechel DE, Mugnaini E, Tappaz ML, Kopin IJ (1981b) Immunocytochemical localization of glutamate decarboxylase in rat cerebellum with a new antiserum. Neuroscience 6:2715-2735.

Okamura H, Abitbol M, Julien J-F, Dumas S, Bérod A, Geffard M, Kitahama K, Bobillier P, Mallet J, Wiklund L (1990) Neurons containing messenger RNA encoding glutamate decarboxylase in rat hypothalamus demonstrated by in situ hybridization, with special emphasis on cell groups in medial preoptic area, anterior hypothalamic area and dorsomedial hypothalamic nucleus. Neuroscience 39:675699.

Perez de la Mora M, Possani LD, Tapia R, Teran L, Palacios R, Fuxe K, Hökfelt T, Ljungdahl A (1981) Demonstration of central gammaaminobutyrate-containing nerve terminals by means of antibodies against glutamate decarboxylase. Neuroscience 5:875-895.

Retaux S, Julien JF, Besson MJ, Penit-Soria J (1992) Expression of GAD mRNA in GABA interneurons of the rat medial frontal cortex. Neurosci Lett 136:67-71.

Ribak CE, Vaughn JE, Saito K (1978) Immunocytochemical localization of glutamic acid decarboxylase in neuronal somata following colchicine inhibition of axonal transport. Brain Res 140:315-332.

Rimvall K, Martin DL (1992) Increased intracellular $\gamma$-aminobutyric acid selectively lowers the level of the larger of two glutamate decarboxylase proteins in cultured GABAergic neurons from rat cerebral cortex. J Neurochem 58:158-166.

Rimvall K, Sheikh SN, Martin DL (1993) Effects of increased $\gamma$-aminobutyric acid levels on $\mathrm{GAD}_{67}$ protein and mRNA levels in rat cerebral cortex. J Neurochem 60:714-720.

Saito K, Barber R, Wu J-Y, Matsuda T, Roberts E, Vaughn JE (1974) Immunohistochemical localization of glutamic acid decarboxylase in rat cerebellum. Proc Natl Acad Sci USA 71:269-273.

Salganicoff L, De Robertis E (1965) Subcellular distribution of the enzymes of the glutamic acid, glutamine and $\gamma$-aminobutyric acid cycles in rat brain. J Neurochem 12:287-309.

Salin P, Chesselet M-F (1993) Expression of GAD $(M, 67,000)$ and its messenger RNA in basal ganglia and cerebral cortex after ischemic cortical lesions in rats. Exp Neurol 119:291-301.

Sambrook J, Fritsch EF, Maniatis T (1989) Molecular cloning: a laboratory manual, $2 \mathrm{~d}$ ed. Cold Spring Harbor: Cold Spring Harbor Laboratory.

Segovia J, Tillakaratne NJK, Whelan K, Tobin AJ, Gale K (1990)
Parallel increases in striatal glutamic acid decarboxylase activity and mRNA levels in rats with lesions of the nigrostriatal pathway. Brain Res 529:345-348.

Segovia J, Castro R, Notario V, Gale K (1991) Transplants of fetal substantia nigra regulate glutamic acid decarboxylase gene expression in host striatal neurons. Mol Brain Res 10:359-362.

Soghomonian J-J, Chesselet M-F (1992) Effects of nigrostriatal lesions on the levels of messenger RNAs encoding two isoforms of glutamate decarboxylase in the globus pallidus and entopeduncular nucleus of the rat. Synapse 11:124-133.

Soghomonian J-J, Gonzales C, Chesselet M-F (1992) Messenger RNAs encoding glutamate-decarboxylase are differentially affected by nigrostriatal lesions in subpopulations of striatal neurons. Brain Res 576:68-79.

Solimena M, Aggujaro D, Muntzel C, Dirkx R, Butler M, DeCamilli P, Hayday A (1993) Association of GAD-65, but not of GAD-67, with the Golgi complex of transfected Chinese hamster ovary cells mediated by the N-terminal region. Proc Natl Acad Sci USA 90: 3073-3077.

Tillakaratne NJK, Erlander MG, Collard MW, Greif KF, Tobin AJ (1992) Glutamate decarboxylase in nonneural cells of rat testis and oviduct: differential expression of GAD65 and GAD67. J Neurochem 58:618-627.

Vernier P, Julien J-F, Rataboul P, Fourrier O, Feuerstein C, Mallet J (1988) Similar time course changes in striatal levels of glutamic acid decarboxylase and proenkephalin mRNA following dopaminergic deafferentation in the rat. I Neurochem 51:1375-1380.

Watson RE Jr, Wiegand SJ, Clough RW, Hoffman GE (1986) Use of cryoprotectant to maintain long-term peptide immunoreactivity and tissue morphology. Peptides 7:155-159.

Wu J-Y, Matsuda T, Roberts E (1973) Purification and characterization of glutamate decarboxylasc from mousc brain. J Biol Chem 248: 3029-3034.

Wuenschell CW, Fisher RS, Kaufman DL, Tobin AJ (1986) In situ hybridization to localize mRNA encoding the neurotransmitter synthetic enzyme glutamate decarboxylase in mouse cerebellum. Proc Natl Acad Sci USA 83:6193-6197.

Wyborski RJ, Bond RW, Gottlieb DI (1990) Characterization of a cDNA coding for rat glutamic acid decarboxylase. Mol Brain Res 8:193-198. 